A modified version of this manuscript has been accepted by the Journal of Survey Statistics and Methodology on $17^{\text {th }}$ March 2015. Please refer to this paper for citation.

To cite:

Durrant, G.B., Maslovskaya, O., Smith, P.W. (2015) Modelling Final Outcome and Length of Call to Improve Efficiency in Call Scheduling, Journal of Survey Statistics and Methodology, forthcoming.

\title{
Modelling Final Outcome and Length of Call Sequence to Improve Efficiency in Interviewer Call Scheduling
}

Gabriele B. Durrant, Olga Maslovskaya and Peter W.F. Smith

Southampton Statistical Sciences Research Institute

University of Southampton, United Kingdom

(g.durrant@southampton.ac.uk)

Address for correspondence:

Gabriele Durrant

Southampton Statistical Sciences Research Institute

University of Southampton

SO17 1BJ, Southampton

United Kingdom

g.durrant@southampton.ac.uk 


\begin{abstract}
:
Survey practitioners are increasingly interested in how best to use paradata to improve data collection processes. One particular question is if it is possible to identify early on during fieldwork sample cases that may require a long time, and therefore a lot of financial and staff resources, until interviewing is completed. More specifically, we aim to identify cases with long unsuccessful call sequences. This paper models call record data predicting final call outcome and length of a call sequence. Separate binary and joint multinomial logistic models for the two outcomes are presented, accounting for the clustering of households within interviewers. Of particular interest is to identify explanatory variables that predict final outcome and length of a call sequence. The study uses data from Understanding Society, a large-scale UK longitudinal survey. The work has implications for responsive and adaptive survey designs. The results indicate that modelling outcome and length of a call sequence jointly improves the fit of the model. Outcomes of previous calls, in particular from the most recent call, are highly predictive. The timing of calls and interviewer observation variables, although significant in the models, only slightly improve the predictive power.
\end{abstract}

Key Words: survey non-response, interviewer call record data, paradata, call sequence, responsive and adaptive survey designs. 


\section{Acknowledgement}

This work was supported by the UK Economic and Social Research Council (ESRC), 'The Use of Paradata in Cross-Sectional and Longitudinal Research’ [grant number: RES-062-23-2997], grant holders: Gabriele B. Durrant, Peter W. F. Smith and Frauke Kreuter.

\section{Data Statement}

This study uses Wave 1 data from Understanding Society, the United Kingdom Household Longitudinal Study (UKHLS). The data were obtained from the UK Data Archive (http://www.data-archive.ac.uk/). Data reference: University of Essex. Institute for Social and Economic Research and National Centre for Social Research, Understanding Society: Wave 1-3, 2009-2012. 5th Edition. Colchester, Essex: UK Data Archive, November 2013. SN: 6614, http://dx.doi.org/10.5255/UKDA-SN-6614-5 


\section{Introduction}

For interviewer administered surveys many statistical agencies nowadays routinely collect call record data. Examples of such data are recordings of the day, time and outcome of each call or visit and any observations made about the person talked to at the call. For face-to-face surveys a range of interviewer observation variables, such as physical and social characteristics of the selected household and neighbourhood, may also be recorded. Researchers have become increasingly interested in how best to use and analyse such information. It is hoped that a better understanding of the calling patterns and the mechanisms leading to particular call sequences help improve data collection through reducing both costs and non-sampling errors. For statistical agencies, investigating time and effort into repeated calls and follow-ups to a sample unit is very resource- and cost-intensive. It is therefore desirable to avoid long unsuccessful call sequences to improve efficiency of call scheduling. The aim is to identify cases prone to long and unsuccessful call sequences.

This paper presents models for call record data predicting final call outcome and length of a call sequence early on in the data collection process, say after the first three calls. Separate binary logistic models and a multinomial logistic model for the two outcomes combined are considered. The clustering of sample cases within interviewers is taken into account by using robust standard error estimation. To assess the accuracy of the models, a range of methods are employed, including the widely used $\mathrm{R}^{2}$ statistic and classification tables (Agresti 2013). Concepts from epidemiology are introduced here into the context of survey methodology including discrimination and prediction (Plewis, Ketende, and Calderwood 2012; Pepe 2003). A particular focus is the identification of explanatory variables that predict final outcome and/or length, especially those characterising long unsuccessful call sequences. Further research 
questions that we aim to address in this study are: how can call record predictors best be incorporated into the model(s): as summary statistics or as individual outcomes?; how predictive are the models?; does their ability to predict improve once more and more call record data are available?; can we achieve similarly performing models by using fully observed auxiliary variables available prior to any data collection?; how can these models best be used in adaptive and responsive survey designs?

Past research mostly aimed to predict final non-response, often did not include paradata and relied on fully observed frame data or socio-demographic variables. However, such models have not been found to predict well the outcomes of calls (Groves and Couper 1996; Groves and Couper 1998; Bates, Dahlhamer, and Singer 2008). In recent years, researchers have explored the potentials of including newly available paradata, such as call record data and interviewer observation variables, in models for non-response outcomes with some success (Potthoff, Manton, and Woodbury 1993; Groves and Couper 1996; Sinibaldi, Durrant, and Kreuter 2013; Sinibaldi, Trappmann, and Kreuter 2014; Bates, Dahlhamer, and Singer 2008; Wagner 2013a and 2013b; Kreuter et al. 2010), but typically still with low predictive power $\left(\mathrm{R}^{2}\right.$ values between 3\%-8\%) (Olson, Smyth, and Wood 2012; Olson and Groves 2012; West and Groves 2013). Also, the length of a call sequence to obtain a response has not been the focus and has been, if at all, used only as an explanatory variable in models. Furthermore, the use of discrete time event history analysis to predict the outcome at the next call rather than the final outcome has been advocated, exploiting call record data as explanatory variables (Groves and Heeringa 2006; Durrant, D’Arrigo, and Steele 2011 and 2013; Durrant, D’Arrigo, and Müller 2013; Sinibaldi 2014; Hanly 2014). However, specialised software and knowledge of such modelling techniques 
are required. Also the outcome over the next few calls may be of greater interest than the outcome of the next call only.

One novel aspect of this paper is to consider modelling both length and outcome of call sequences simultaneously. For comparison, separate and joint models for the two outcomes are developed. The method proposed employs standard modelling techniques, which is an advantage. The study uses data from a large-scale face-to-face longitudinal survey in the UK, Understanding Society. The research is motivated by findings from a recent sequence analysis of the same data (Durrant, Maslovskaya and Smith 2014), which highlights the importance of sequence length and outcome as two key characteristics of the large number of different sequences, supporting findings from earlier work (Kreuter and Kohler 2009). This analysis identified a significant number of long call sequences (up to 30 calls) for some households and a distinct grouping of sequences into short and long, successful and unsuccessful call sequences.

The research has implications for survey practice, in particular for adaptive and responsive survey designs. The method developed may be of particular benefit for longitudinal surveys, where the same or similar auxiliary variables, are available for every wave. The models could then be used to predict final outcome and sequence length for future waves.

The remainder of the paper is structured as follows. First, the Understanding Society survey and the analysis sample are discussed. The methods section presents the logistic regression models, the modelling strategy and methods to compare and assess different models. Then, the results are presented. The paper concludes with a summary of the main findings, implications for survey practice, limitations and further work. 


\section{Data}

\subsection{The Understanding Society Survey}

This paper uses call record data and interviewer observations from the first wave of the UK Understanding Society survey, which is the Household Longitudinal Study in the United Kingdom. The survey covers topics of health, work, education, income, family and social life to help understand the long term effects of social and economic change, as well as policy interventions. The study has many advantages over previously existing datasets in the UK by being exceptionally large and comprehensive. In particular, as part of the study a range of paradata were collected, including call record data and a wide range of interviewer observation variables. Also, only interviewers with above average experience and ability were selected for the study.

Data collection for each wave is scheduled across a 24-months period, with interviews taking place annually. Wave 1 data collection took place between January 2009 and March 2011. All Wave 1 interviews were carried out face-to-face in respondents' homes by trained interviewers using computer-assisted personal interviewing (CAPI). Households are therefore clustered within interviewers. All adult household members (age 16 and older) are asked to respond. In addition to individual interviews, a member of the household needs to respond to a household questionnaire. Interviewers have one month to contact households. A minimum of six calls are made at each sampled address before it is considered unproductive, but interviewers are encouraged to make further calls if possible (McFall 2012).

During the first visit to a household, interviewers collect a wide range of interviewer observations capturing characteristics about each household and surrounding neighbourhood. 
(see online Appendix Table A1 for wording of all variables considered). In addition, call record data are available, which capture information about each call, including outcome, date and time of each call. The outcome of a call in the Understanding Society survey is defined as non-contact, contact, appointment, interview, and 'any other status' (which includes ineligibles and refusals). For this study, call record data, including final response outcome, are combined with interviewer observation data, variables about the study design and geographic information, using a unique household identifier. All variables are available for both respondents and non-respondents.

\subsection{Analysis sample and definition of response and explanatory variables}

The analysis was initially carried out on all households from Wave 1, excluding cases from an Ethnic Minority Boost sample as rules for the selection of this sample differ from the main sample. A separate analysis could be undertaken for this group. This distinction is, however, not of interest here. Ineligibles are included in our analysis since it is a true outcome and survey agencies may be interested in mechanisms for identifying ineligibles as early as possible to reduce survey costs. This initial analysis sample contained 47,913 households (including both responding and non-responding households). First, we carried out preliminary work using this initial analysis sample, conducting separate analyses for all cases with at least 1, 2, 3 etc. calls. The aim was to evaluate after every call, how well we can predict final outcome and length as more information about each case becomes available. This preliminary analysis suggested that 3 calls may be sufficient to reach an acceptable level of predictability. To more formally assess this and to be able to compare model fit and prediction across the different models -since measures of predictability are dependent on sample size- we restrict our final analysis sample to all households from Wave 1 that received four or more calls (27,995 households). This approach enables us to employ call record information from the beginning of the field period (here the first 
three calls) to predict final length and outcome. For these final models, we also excluded a small number of cases with missing values in the explanatory variables, as follows: there are no missing cases in any of the geographic information and design variables since these are derived from administrative data. Date and time of a call are automatically captured using computer assisted methods leading to no missing cases in these variables. Recordings of the call outcome, contained a very small amount of missing data, and such calls were excluded (311 cases). Households with missing items in the interviewer observation variables were deleted (2,015 cases). The final analysis sample, including only cases with four or more calls, contains 25,358 households within 734 interviewers.

To analyse length and call outcome (and to ensure the comparability of the different models), the following three response variables are considered. Their distributions are presented in Table 1.

1.) length of call sequence (binary), distinguishing short sequences (up to 6 calls) and long sequences (more than 6 calls). The cut-off point at 6 calls was intentionally selected to fit with the survey protocol requirements of conducting a minimum of 6 call attempts if contact was not established earlier in the process.

2.) (final) outcome of call sequence (binary), distinguishing successful call sequences with at least one interview conducted in a household (after call 3) and unsuccessful call sequences with no interviews achieved (after call 3).

3.) a variable combining both length and final outcome, distinguishing 4 categories - short unsuccessful (up to 6 calls, no interview), short successful (up to 6 calls, at least one interview after call 3), long unsuccessful (more than 6 calls, no interview) and long successful (more than 6 calls, at least one interview after call 3). 
(Different definitions of the dependent variables - such as complete household outcome and different categorisations of sequence length - were also explored. The overall conclusions were very similar to the ones presented in this paper.)

Table 1: Distributions of the three response variables in the final analysis sample $(25,358$ households).

\begin{tabular}{|c|c|c|}
\hline Variables with categories & Frequencies & Percentages \\
\hline \multicolumn{3}{|l|}{ Length } \\
\hline Short sequence (up to 6 calls) & 12353 & 48.7 \\
\hline Long sequence (7-30 calls) & 13005 & 51.3 \\
\hline \multicolumn{3}{|l|}{ Final outcome } \\
\hline No single interview in a sequence & 13565 & 53.5 \\
\hline At least one interview in a sequence & 11793 & 46.5 \\
\hline \multicolumn{3}{|l|}{ Combined response } \\
\hline Short unsuccessful & 4962 & 19.6 \\
\hline Short successful & 7391 & 29.1 \\
\hline Long unsuccessful & 8603 & 33.9 \\
\hline Long successful & 4402 & 17.4 \\
\hline
\end{tabular}

The explanatory variables used in the analysis can be split into three main groups. The distributions of the explanatory variables broken down by the categories of the response variables are presented in the online Appendix (Table A2).

1.) geographic information and design variables (4 variables: urban/rural indicator, government office region, low density area for ethnic minorities and month of household issue);

2.) interviewer observation variables (14 variables, e.g. indicators of entry barriers, conditions of surrounding area such as litter in street, abandoned buildings, heavy traffic, type of accommodation, presence of children in a household, relative condition of the property, garden); 
3.) call record variables ( 20 variables, e.g. date, time of day, day of week, call outcome; also derived variables including time between calls, number of previous non-contacts, contacts, appointments and broken appointments).

\section{Methods}

\subsection{Binary and multinomial regression models}

To model length and final outcome binary logistic regression analysis is used. Multinomial logistic regression is employed to model the combined response variable as it contains four categories. To correctly control for the clustering of households within interviewers robust standard error estimation is employed (Huber 1967; White 1980, 1984 and 1994). As an alternative modelling approach, multilevel models could have been employed also allowing for the nesting of households within interviewers. However, since interviewer effects are not of substantive interest here (e.g. we are not interested in explaining effects of contextual or interviewer-level variables), a multilevel modelling approach is not necessary. To assess predictability of different models $\mathrm{R}^{2}$ statistics and classification tables are obtained.

We denote by $\mathrm{y}_{\mathrm{i}}$ a binary response variable of household $\mathrm{i}$. The dependent variable 'length of call sequence' is coded

$$
\mathrm{y}_{\mathrm{i}}= \begin{cases}1 & \text { short call sequence (up to } 6 \text { calls) } \\ 0 & \text { long call sequence (more than } 6 \text { calls) }\end{cases}
$$

and the dependent variable 'final outcome of call sequence' is coded

$$
\mathrm{y}_{\mathrm{i}}= \begin{cases}1 & \text { successful call sequence (at least one interview after call 3) } \\ 0 & \text { unsuccessful call sequence (no interview after call 3). }\end{cases}
$$

The response probabilities are denoted by $\pi_{\mathrm{i}}=\operatorname{Pr}\left(\mathrm{y}_{\mathrm{i}}=1\right)$ and are related to the explanatory variables using logistic regression (e.g. Agresti 2013): 


$$
\operatorname{logit}\left(\pi_{\mathrm{i}}\right)=\log \left(\frac{\pi_{\mathrm{i}}}{1-\pi_{\mathrm{i}}}\right)=\boldsymbol{\beta}^{\mathrm{T}} \mathbf{x}_{\mathrm{i}}
$$

where $\mathbf{x}_{\mathrm{i}}$ is a vector of household-level covariates including intercept and interactions, and $\boldsymbol{\beta}$ is a vector of coefficients.

Multinomial logistic regression is an extension of binary logistic regression. If the response variable has S categories, then the multinomial logistic regression model can be expressed as a set of S-1 non-redundant logistic model equations. We denote by $\mathrm{y}_{\mathrm{i}}$ the dependent variable which combines length and final outcome in household i, coded

$$
y_{i}= \begin{cases}1 & \text { short successful } \\ 2 & \text { short unsuccessful } \\ 3 & \text { long successful } \\ 4 & \text { long unsuccessful }\end{cases}
$$

The response probabilities are denoted by $\pi_{\mathrm{i}}^{(\mathrm{s})}=\operatorname{Pr}\left(\mathrm{y}_{\mathrm{i}}=\mathrm{s}\right)$, s=1, 2, 3, 4. Taking 'long unsuccessful' as the reference category, the multinomial logistic regression model can be expressed as

$$
\log \left(\frac{\pi_{\mathrm{i}}^{(\mathrm{s})}}{\pi_{\mathrm{i}}^{(4)}}\right)=\boldsymbol{\beta}^{(\mathrm{s})^{\mathrm{T}}} \mathbf{x}_{\mathrm{i}}^{(\mathrm{s})}, \mathrm{s}=1,2,3,
$$

where $\mathbf{x}_{\mathrm{i}}^{(\mathrm{s})}$ is a vector of covariates including intercept and interactions, and $\boldsymbol{\beta}^{(\mathrm{s})}$ is a vector of coefficients.

\subsection{Modelling strategy and comparison of models}

Likelihood ratio tests (using the change in the $L^{2}$ goodness-of-fit statistic) are used to test the significance of a term in the model. For data preparation and analysis we used SPSS version 
20 and STATA 12. STATA can estimate robust standard errors to control for the nonindependence of observations (ro function; Long and Freese 2006). To simplify the interpretation of the modelling results predicted probabilities are obtained for specific variables, holding all other variables constant at their means.

\section{Modelling Strategy}

A forward stepwise model selection procedure is employed. Explanatory variables, together with selected interaction effects, are included into the models: first, only geographic and design variables are included; then interviewer observations are added. Information about the timing of the first call attempt follows, then timing of second and third call (including time between calls). Information about the outcome for the first three calls are added one by one and then as combinations, either as raw outcomes (i.e. outcome of first, second and third call, interactions between outcomes) or as summary information (i.e. number of non-contacts, contacts, appointment and interviews across the first three calls). Allowing for interaction effects between outcomes accounts for the sequence of outcomes as a whole rather than simply as individual outcomes. For example, a non-contact call after an appointment should be interpreted differently from a non-contact after a previous non-contact. The former may reflect an indirect refusal, whereas the latter indicates a longer period of absence. At the last stage of the modelling strategy, time of day and day of the week of the fourth call is added to the models, but without call outcome of call 4. Here, we would like to know if we can predict length and outcome after say three calls when the fourth call is about to start, assuming the timing of the call the interviewer would have chosen. In total, 19 models for each response variable were fitted to the final analysis sample (57 models overall). Only selected models will be discussed further in this paper. It should be noted 
that ideally survey researchers would want to control for household size in the models. Here, this was not directly possible since this variable is only observed for responding households. Although there is no direct measure of household size from the interviewer observation variables in Understanding Society, a number of proxy measures are used, such as type of accommodation, floor level and presence of children.

\section{Comparison of model performance}

To compare the different models and to assess the quality of model predictions and model fits, we employ the $\mathrm{R}^{2}$ statistic and classification tables. The $\mathrm{R}^{2}$ coefficient focuses on prediction and is a measure of the goodness-of-fit. It represents the proportion of variation in the dependent variable that is explained by the model, ranging from 0 to 1 . The closer it is to 1 , the greater the proportion of variation explained by the model. The better the fit of the model, the more confidence it provides that the regression-based predictions are accurate. A number of pseudo- $\mathrm{R}^{2}$ measures exist for logistic regression models, e.g. Cox and Snell, McFadden and Nagelkerke $\mathrm{R}^{2}$. Different pseudo- $\mathrm{R}^{2}$ coefficients can produce different values. The Cox and Snell and the McFadden $\mathrm{R}^{2}$ shows the improvement of the model over the null model. The main limitation of these coefficients is that they do not reach the maximum value of 1 which makes the interpretation of the coefficient more difficult (Field 2009; Long and Freese 2006). The Nagelkerke $\mathrm{R}^{2}$ coefficient adjusts the Cox and Snell $\mathrm{R}^{2}$ so that the range of possible values extends to 1 for ease of interpretation (Field 2009). Here, the Nagelkerke $\mathrm{R}^{2}$ coefficient is employed. 
Although the $\mathrm{R}^{2}$ statistic is widely used to assess the prediction performance of nonresponse models (Groves and Couper 1998; Bates, Dahlhamer, and Singer 2008), it is designed to assess the overall fit of the model and therefore does not distinguish between the accuracy of the model for respondents and non-respondents separately (Plewis, Ketende, and Calderwood 2012). To achieve this we borrow ideas from concepts widely used in epidemiology. Accuracy may be determined by two related concepts: discrimination and prediction (Pepe 2003). Discrimination refers to the conditional probability that a household is predicted to be a respondent (non-respondent) given that a household is indeed a respondent (non-respondent). Prediction refers to the conditional probability of being a respondent (non-respondent) given a household is predicted to be a respondent (non-respondent) (Plewis, Ketende, and Calderwood 2012). To evaluate both concepts classification tables are derived cross-classifying the observed binary response with a prediction of whether $\mathrm{y}_{\mathrm{i}}=0$ or $\mathrm{y}_{\mathrm{i}}=1$ (Agresti 2013). The prediction for an observation will be obtained depending on a cut-off $\pi_{0}$. The prediction for observation $\mathrm{i}$ is $\hat{\mathrm{y}}_{\mathrm{i}}=1$ if $\hat{\pi}_{\mathrm{i}}>\pi_{0}$, and $\hat{\mathrm{y}}_{\mathrm{i}}=0$ if $\hat{\pi}_{\mathrm{i}} \leq \pi_{0}$, where $\hat{\pi}_{\mathrm{i}}$, denotes the predicted probability from the model. The discrimination power may be summarised by sensitivity $=\mathrm{P}\left(\hat{\mathrm{y}}_{\mathrm{i}}=1 \mid \mathrm{y}_{\mathrm{i}}=1\right)$ (or true positive fraction) and specificity $=\mathrm{P}\left(\hat{\mathrm{y}}_{\mathrm{i}}=0 \mid \mathrm{y}_{\mathrm{i}}=0\right)$ (1 minus the false positive fraction) (Agresti 2013; Plewis, Ketende, and Calderwood 2012; Altman 1991). As an overall summary measure of model performance, the percentage of observations correctly classified may be used (i.e. a summary of the diagonal of the classification table), which is a weighted average of sensitivity and specificity:

$$
\begin{aligned}
\mathrm{P}(\text { correctly classified }) & =\mathrm{P}\left(\mathrm{y}_{\mathrm{i}}=1 \text { and } \hat{\mathrm{y}}_{\mathrm{i}}=1\right)+\mathrm{P}\left(\mathrm{y}_{\mathrm{i}}=0 \text { and } \hat{\mathrm{y}}_{\mathrm{i}}=0\right) \\
& =\mathrm{P}\left(\hat{\mathrm{y}}_{\mathrm{i}}=1 \mid \mathrm{y}_{\mathrm{i}}=1\right) \mathrm{P}\left(\mathrm{y}_{\mathrm{i}}=1\right)+\mathrm{P}\left(\hat{\mathrm{y}}_{\mathrm{i}}=0 \mid \mathrm{y}_{\mathrm{i}}=0\right) \mathrm{P}\left(\mathrm{y}_{\mathrm{i}}=0\right) .
\end{aligned}
$$


The concept of prediction is useful, since it tackles the problem from the other direction. In practice, survey researchers would not know who will be a respondent or a non-respondent before the end of data collection. This means we are interested in the probability of the prediction being correct whether the household is in reality a respondent or a non-respondent. These are measured by the positive predictive value, $\mathrm{P}\left(\mathrm{y}_{\mathrm{i}}=1 \mid \hat{\mathrm{y}}_{\mathrm{i}}=1\right)$, and the negative predictive value, $\mathrm{P}\left(\mathrm{y}_{\mathrm{i}}=0 \mid \hat{\mathrm{y}}_{\mathrm{i}}=0\right)$. The concepts of classification table, discrimination and prediction can be extended to the multinomial case, allowing for several groups of misclassifications. For a 4 category variable this results in a $4 \times 4$ classification table, allowing for 4 correctly and 12 incorrectly classified groups. In this analysis we are particularly interested in predicting nonresponse and in discriminating between respondents and non-respondents. In the results section we therefore refer to sensitivity and positive predicted values with respect to modelling long and unsuccessful call sequences. In our analysis we use the default option of $\pi_{0}=0.50$ for the binary and $\pi_{0}=0.25$ for the multinomial case, although in practice different values can be explored to optimise the balance between discrimination and prediction (Plewis, Ketende, and Calderwood 2012). Since both the $\mathrm{R}^{2}$ statistics and the classification tables allows the comparison of different models for the same data, the final analysis sample was restricted to households with 4 or more calls, although in survey practice the models can be fitted to either all cases or restricted samples, such as all households with at least 1, 2, 3 calls etc.

\section{Results}

First, a range of models with increasing amount of explanatory variables are fitted to each of the three dependent variables. Table 2 presents pseudo- $\mathrm{R}^{2}$ coefficients and the results from the classification tables of the percentage of correctly classified households for eight selected 
models. To be able to interpret the results from the classification tables correctly let us consider a random allocation of households into different categories of the response variables. For a binary dependent variable we would expect $50 \%$ of cases to be correctly allocated to one of the two groups at random (e.g. at least one interview/no interview; short/long call sequence). For the multinomial case with four categories we would expect this percentage to be $25 \%$. So to do better than random allocation, we aim to find classification values above $50 \%$ for the binary and above $25 \%$ for the multinomial case. Table 2 suggests that the predictive power of models only including geographic location and design variables (Model 1) is very low with pseudo- $\mathrm{R}^{2}$ coefficients all below 3\% and only about 55\% of cases being correctly classified for both binary models and 36\% for the multinomial model. The introduction of interviewer observations to the models improves the predictability of the models in relative terms. The $\mathrm{R}^{2}$ value doubles for length, triples for the multinomial model and quadruples for the final outcome variable. However, in absolute terms it is still below 9\% across all three models. The classification of cases improves by 2.8-3.6 percentage points. Despite the relatively low improvement in prediction performance, it should be noted that the majority of interviewer observation variables are found to be highly significant across all models, stressing nevertheless the importance of such variables. The introduction of the call record information in the form of timings of calls slightly improves the models' predictions (Models 3 and 4). The $\mathrm{R}^{2}$ is now around $10 \%$ for the binary and $18 \%$ for the multinomial model with the classification tables around $61 \%$ and $43 \%$ respectively. Including information about call outcomes (Models 5-7) substantially improves the models' prediction. The $\mathrm{R}^{2}$ values increase to around $25 \%$ for the binary case and to even $37 \%$ for the multinomial case. The classification table has increased to $70 \%$ for the binary and 52\% for the multinomial case, reflecting an improvement in the percentage of correctly allocated 
cases by $40 \%$ and by above $100 \%$ in comparison to a random allocation respectively. Comparing the three models including outcome(s) of previous calls, Model 6, which includes raw outcomes for all three calls, performs better with regards to prediction than one outcome on its own (Model 5) or summaries of separate call outcomes (Model 7). As one may expect, the outcome of the last call (here call 3) is the key variable when predicting final outcome and length.

Table 2: Comparison of different models for length, (final) outcome and the combined dependent variable of length and outcome (Nagelkerke $\mathrm{R}^{2}$ and classification table, i.e. the percentage correctly classified households).

\begin{tabular}{|c|c|c|c|c|c|c|c|}
\hline \multirow{2}{*}{\multicolumn{2}{|c|}{ Model }} & \multicolumn{2}{|c|}{ Length } & \multicolumn{2}{|c|}{ Partial Outcome } & \multicolumn{2}{|c|}{ Combined Outcome } \\
\hline & & $\begin{array}{c}\text { Nagelkerke } \\
\mathbf{R}^{2}\end{array}$ & $\begin{array}{c}\text { Classification } \\
\text { table }\end{array}$ & $\begin{array}{c}\text { Nagelkerke } \\
\mathrm{R}^{2}\end{array}$ & $\begin{array}{c}\text { Classification } \\
\text { table }\end{array}$ & $\begin{array}{c}\text { Nagelkerke } \\
\mathrm{R}^{2}\end{array}$ & $\begin{array}{c}\text { Classification } \\
\text { table }\end{array}$ \\
\hline 1 & $\begin{array}{l}\text { Just } \\
\text { geographic }\end{array}$ & 0.027 & $55.5 \%$ & 0.013 & $54.6 \%$ & 0.029 & $36.2 \%$ \\
\hline 2 & $\begin{array}{l}\text { 1+interviewer } \\
\text { observations }\end{array}$ & 0.062 & $58.7 \%$ & 0.053 & $58.2 \%$ & 0.085 & $39.0 \%$ \\
\hline 3 & $\begin{array}{l}2+\text { call record } \\
\text { for call } 1 \\
\text { including call } \\
\text { outcome }\end{array}$ & 0.078 & $59.9 \%$ & 0.065 & $59.4 \%$ & 0.115 & $40.3 \%$ \\
\hline 4 & $\begin{array}{l}2+\text { call record } \\
\text { for calls } 1-3 \\
\text { without call } \\
\text { outcomes }\end{array}$ & 0.110 & $61.1 \%$ & 0.105 & $61.2 \%$ & 0.185 & $42.9 \%$ \\
\hline 5 & $\begin{array}{l}4+\text { call } \\
\text { outcome for } \\
\text { call } 3\end{array}$ & 0.248 & $69.1 \%$ & 0.236 & $67.4 \%$ & 0.360 & $51.2 \%$ \\
\hline 6 & $\begin{array}{l}4+\text { call } \\
\text { outcomes for } \\
\text { calls } 1-3\end{array}$ & 0.258 & $69.7 \%$ & 0.242 & $67.8 \%$ & 0.371 & $51.7 \%$ \\
\hline 7 & $\begin{array}{l}4+4 \text { sums of } \\
\text { call outcomes } \\
\text { across the } \\
\text { calls } 1-3\end{array}$ & 0.224 & $68.4 \%$ & 0.209 & $66.9 \%$ & 0.332 & $50.4 \%$ \\
\hline 8 & $\begin{array}{l}6+\text { call record } \\
\text { for call } 4 \\
\text { without call } \\
\text { outcome for } \\
\text { call } 4\end{array}$ & 0.270 & $70.7 \%$ & 0.264 & $68.5 \%$ & 0.400 & $52.9 \%$ \\
\hline
\end{tabular}


Out of curiosity, we also fit a model that controls for the day and time of call 4 chosen by the interviewer for visiting a household, pretending call 4 has not yet happened. Although this further improves the prediction performance of the models, the level of improvement is not substantial when compared to Model 6 (changes in $\mathrm{R}^{2}$ vary between 1-3\% and classification improves by a maximum of $1.2 \%$ ). Table 2 suggests that the best models for prediction is obtained in Model 6 which contains variables from the geographic and design group, interviewer observations and call record data including raw call outcomes for the first three calls and timing of calls. Also, modelling outcome and length of call sequence jointly improves the fit of the model in comparison to the two separate models for either length or final outcome based on the $\mathrm{R}^{2}$ value and the classification table.

Table 3: Results of the classification table showing the percentage of correctly classified households by categories of the multinomial dependent variable (combined length and outcome) for each of the 8 modelling stages considered. (Column percentages shown, i.e. percentage of those households which were estimated correctly out of the total observed in the group).

\begin{tabular}{lcccc}
\hline Model & $\begin{array}{c}\text { Short } \\
\text { Unsuccessful } \\
(\mathbf{n = 4 9 6 2 )}\end{array}$ & $\begin{array}{c}\text { Short } \\
\text { Successful } \\
\text { (n=7391) }\end{array}$ & $\begin{array}{c}\text { Long } \\
\text { Unsuccessful } \\
(\mathbf{n = 8 6 0 3 )}\end{array}$ & $\begin{array}{c}\text { Long } \\
\text { Successful } \\
(\mathbf{n = 4 4 0 2})\end{array}$ \\
\hline 1 & $0.0 \%$ & $43.2 \%$ & $69.6 \%$ & $0.0 \%$ \\
2 & $6.5 \%$ & $52.8 \%$ & $65.9 \%$ & $0.1 \%$ \\
3 & $20.4 \%$ & $49.8 \%$ & $64.2 \%$ & $0.1 \%$ \\
4 & $31.1 \%$ & $51.6 \%$ & $63.9 \%$ & $0.4 \%$ \\
5 & $44.3 \%$ & $50.2 \%$ & $79.5 \%$ & $5.2 \%$ \\
6 & $45.1 \%$ & $51.0 \%$ & $79.5 \%$ & $5.6 \%$ \\
7 & $42.2 \%$ & $54.4 \%$ & $75.3 \%$ & $3.9 \%$ \\
8 & $50.7 \%$ & $52.5 \%$ & $78.2 \%$ & $6.8 \%$ \\
\hline
\end{tabular}

In the non-response literature researchers are interested in predicting the non-respondents correctly. More specifically for this application, we are interested in predicting households with no interview and long call sequences early on in the data collection process. Table 3 shows the percentage of correctly classified households by the categories of the multinomial dependent 
variable for each of the 8 modelling stages considered. Across all stages the percentage of correctly classified households with long unsuccessful call sequences (around 64-80\%) is quite high. For Model 6 this value increases to 80\%, meaning that of the cases that have long unsuccessful call sequences $80 \%$ are correctly classified by the model as being indeed in this category.

Table 4: Complete classification table for the multinomial model (dependent variable is combined length and outcome) for Model 6: (A) column percentages (percentages predicted out of the total observed in the category) reflecting sensitivity of modelling long unsuccessful calls and (B) row percentages (percentages of households observed in the group out of the total predicted in the category) reflecting positive predictive values.

\begin{tabular}{|c|c|c|c|c|c|c|}
\hline & & & \multicolumn{4}{|c|}{ Observed } \\
\hline & & & $\begin{array}{c}\text { Short } \\
\text { Unsuccessful } \\
(n=4962)\end{array}$ & $\begin{array}{c}\text { Short } \\
\text { Successful } \\
(\mathbf{n}=7391) \\
\end{array}$ & $\begin{array}{c}\text { Long } \\
\text { Unsuccessful } \\
(\mathbf{n}=\mathbf{8 6 0 3})\end{array}$ & $\begin{array}{c}\text { Long } \\
\text { Successful } \\
(n=4402) \\
\end{array}$ \\
\hline \multirow[t]{4}{*}{$\mathbf{A}$} & Predicted & $\begin{array}{l}\text { Short } \\
\text { Unsuccessful }\end{array}$ & $45.1 \%$ & $6.8 \%$ & $9.8 \%$ & $5.2 \%$ \\
\hline & & $\begin{array}{l}\text { Short } \\
\text { Successful }\end{array}$ & $13.4 \%$ & $51.0 \%$ & $8.8 \%$ & $16.8 \%$ \\
\hline & & $\begin{array}{l}\text { Long } \\
\text { Unsuccessful }\end{array}$ & $40.6 \%$ & $39.8 \%$ & $79.5 \%$ & $72.4 \%$ \\
\hline & & $\begin{array}{l}\text { Long } \\
\text { Successful } \\
\end{array}$ & $0.9 \%$ & $2.4 \%$ & $1.9 \%$ & $5.6 \%$ \\
\hline \multirow[t]{4}{*}{ B } & Predicted & $\begin{array}{l}\text { Short } \\
\text { Unsuccessful }\end{array}$ & $58.7 \%$ & $13.1 \%$ & $22.1 \%$ & $6.1 \%$ \\
\hline & & $\begin{array}{l}\text { Short } \\
\text { Successful }\end{array}$ & $11.2 \%$ & $63.6 \%$ & $12.8 \%$ & $12.4 \%$ \\
\hline & & $\begin{array}{l}\text { Long } \\
\text { Unsuccessful }\end{array}$ & $13.4 \%$ & $19.6 \%$ & $45.7 \%$ & $21.3 \%$ \\
\hline & & $\begin{array}{l}\text { Long } \\
\text { Successful }\end{array}$ & $7.4 \%$ & $28.3 \%$ & $25.2 \%$ & $39.1 \%$ \\
\hline
\end{tabular}

Table 4 breaks this down further for the multinomial model for Model 6, showing marginal summaries of the classification table. The upper panel (A) indicates sensitivity (for a model for long unsuccessful calls) and the lower panel (B) the positive predictive values. For example, we can see that of the cases that are predicted to have long unsuccessful call sequences (panel B) indeed $46 \%$ belong correctly to this category, $13.4 \%$ and $19.6 \%$ would be wrongly 
classified and belong in reality to the short successful and short unsuccessful groups respectively. Misclassification to short sequences would not have in practice negative implications since six calls might be made anyway. Of the cases predicted to have long unsuccessful call sequences $21 \%$ turn out to have long successful calls.

Let us now turn to the discussion of the effects of different explanatory variables on the three outcomes. A number of variables are found to be consistently significant across all models. For example, for length these are months of household issue, urban/rural, region, low density ethnic minority area, some interviewer observation variables (accommodation, floor, car/van, child, unkempt garden, relative condition of property) and some call record variables (time of day, time between calls and call outcome variables). Consistently significant predictors for final outcome are region, interviewer observation variables (floor, car/van, child, relative condition of property), time of day (call 1), time between calls and, as might be expected, all call outcome variables, but, unlike in the models for length, they exclude urban/rural, unkempt garden and low density area. Consistently significant predictors for the combined response models are similar to the model for length alone including geographic and design variables (months, urban/rural, region), interviewer observation variables (locked gates, accommodation, floor, car/van, child, unkempt garden, relative condition of property) and call record variables (all time of day variables, time between calls and call outcome variables). Interestingly, day of the week is not significant in most models.

The results of the final models for all three response variables from Model 6 are discussed below. Table 5 presents estimated regression coefficients together with odds ratios from the two binary logistic models (Model 6). The results suggest that the odds of having a short call sequence are higher in the South West (1.267 times) and Scotland (1.199 times) and 
reduced in London (1.320 times) when compared to the North East. They are also higher in low density areas for ethnic minorities (1.090 times), in rural areas (1.128 times), for properties with 2 or less floors (1.216-2.247 times), for households which definitely do not have a car (1.947 times), are unlikely to have children or do not have children (1.193 and 1.232 times) and if there is no unkempt garden (1.225 times). The odds are lower in terraced houses (1.230 times) and flats (1.344 times) when compared to detached houses, also lower (1.107 times) when properties are worse than others in the neighbourhood, and lower when the calls are made in the evening compared to morning calls. (It should be noted that we cannot interpret this as a causal effect since calling times are not allocated randomly but are merely determined by the interviewer). The model suggests a positive association for time between calls: the longer the time between calls, the higher the probability of a short sequence. Shorter sequences are also more likely when previous call outcomes are a contact, an appointment, any other status or an interview when compared to non-contact. There is a marked monotone increase in the effect of the call outcome variables across the three calls, indicating that although the outcome of each call is significant, it may be the most recent call that has the highest influence, rather than, for example, the first call. An appointment or interview at the third call increases the odds of a short sequence by between 7 to 10 times compared to having a non-contact at this call attempt. 
Table 5: Estimated coefficients for the two logistic regression models for length and (final) outcome including geographic and design variables, interviewer observation variables and call record variables comprising timing and outcome of the call(s) (Model 6).

\begin{tabular}{|c|c|c|c|c|c|c|}
\hline \multirow[b]{2}{*}{ Variable } & \multicolumn{3}{|c|}{ Model for Length } & \multicolumn{3}{|c|}{ Model for (final) outcome } \\
\hline & \multicolumn{2}{|r|}{ Robust } & OR & $\beta$ & Robust & OR \\
\hline Constant & -1.087 & 0.149 & & 0.363 & 0.149 & \\
\hline \multicolumn{7}{|l|}{ Geographic and design variables } \\
\hline \multicolumn{7}{|l|}{ Months } \\
\hline January-June year 1 (ref) & 0.000 & & 1.000 & 0.000 & & 1.000 \\
\hline July-December year 1 & -0.099 & 0.040 & $0.905^{*}$ & 0.154 & 0.040 & $1.167 * * *$ \\
\hline January-June year 2 & -0.213 & 0.039 & $0.808^{* * *}$ & -0.001 & 0.039 & 0.999 \\
\hline July-December year 2 & -0.319 & 0.039 & $0.726^{* * *}$ & 0.016 & 0.039 & 1.017 \\
\hline \multicolumn{7}{|l|}{$\begin{array}{l}\text { Low density area for ethnic } \\
\text { minorities }\end{array}$} \\
\hline No (ref) & 0.000 & & 1.000 & & & \\
\hline Yes & 0.086 & 0.036 & $1.090 *$ & & & \\
\hline \multicolumn{7}{|l|}{ Government Office Region (GOR) } \\
\hline North East (ref) & 0.000 & & 1.000 & 0.000 & & 1.000 \\
\hline North West & 0.091 & 0.079 & 1.095 & -0.164 & 0.077 & $0.848^{*}$ \\
\hline Yorkshire and the Humber & 0.136 & 0.082 & 1.146 & -0.168 & 0.080 & $0.845^{*}$ \\
\hline East Midlands & 0.048 & 0.085 & 1.050 & 0.072 & 0.083 & 1.075 \\
\hline West Midlands & 0.084 & 0.082 & 1.088 & -0.244 & 0.079 & $0.783^{* *}$ \\
\hline East of England & 0.016 & 0.077 & 1.016 & -0.212 & 0.078 & $0.809 * *$ \\
\hline London & -0.282 & 0.082 & $0.754^{* *}$ & -0.449 & 0.075 & $0.638^{* * *}$ \\
\hline South East & 0.061 & 0.077 & 1.063 & -0.250 & 0.074 & $0.779 * *$ \\
\hline South West & 0.237 & 0.083 & $1.267 * *$ & -0.184 & 0.081 & $0.832 *$ \\
\hline Wales & 0.156 & 0.093 & 1.169 & -0.151 & 0.092 & 0.859 \\
\hline Scotland & 0.182 & 0.083 & $1.199 *$ & -0.334 & 0.080 & $0.716^{* * *}$ \\
\hline \multicolumn{7}{|l|}{ Urban/rural } \\
\hline Urban area (ref) & 0.000 & & 1.000 & & & \\
\hline Rural area & 0.121 & 0.040 & $1.128^{* *}$ & & & \\
\hline \multicolumn{7}{|l|}{ Interviewer observations variables } \\
\hline \multicolumn{7}{|l|}{ Accommodation } \\
\hline Detached house/bungalow (ref) & 0.000 & & 1.000 & & & \\
\hline Semi-detached house/bungalow & -0.062 & 0.042 & 0.940 & & & \\
\hline $\begin{array}{r}\text { Terraced house/end terraced } \\
\text { house/bungalow }\end{array}$ & -0.207 & 0.046 & $0.813^{* * *}$ & & & \\
\hline $\begin{array}{r}\text { Flats/maisonettes purpose built or } \\
\text { converted }\end{array}$ & -0.296 & 0.061 & $0.744^{* * *}$ & & & \\
\hline $\begin{array}{l}\text { Bedsitters, dwellings with business } \\
\text { and sheltered accommodation }\end{array}$ & 0.257 & 0.184 & 1.293 & & & \\
\hline \multicolumn{7}{|l|}{ Floor } \\
\hline 0 floors & 0.809 & 0.236 & $2.247 * *$ & 0.806 & 0.213 & $2.238 * * *$ \\
\hline
\end{tabular}




$\begin{array}{rllllll}\text { 1 floor } & 0.318 & 0.078 & 1.374^{* * *} & 0.430 & 0.073 & 1.538^{* * *} \\ 2 \text { floors } & 0.196 & 0.075 & 1.216^{* *} & 0.402 & 0.065 & 1.495^{* * *} \\ \text { 3 floors } & 0.051 & 0.079 & 1.052 & 0.413 & 0.077 & 1.511^{* * *} \\ 4 \text { floors and above (ref) } & 0.000 & & 1.000 & 0.000 & & 1.000\end{array}$

Car/van

Definitely has a car/van (ref)

Likely

Unlikely

Definitely does not have a car/van

Cannot tell from observation

Child

Definitely has a child/children aged under 10 (ref)

Likely

Unlikely

Definitely does not have a child/children aged under 10

Cannot tell from observation

Unkempt garden

$$
\begin{array}{r}
\text { Yes (ref) } \\
\text { No } \\
\text { No obvious garden }
\end{array}
$$$$
\text { No }
$$

0.000

$-0.039$

0.153

0.666

$-0.137$

0.041

0.078

0.095

0.041

0.000

0.013

0.177

0.075

0.068

0.209

0.068

0.062

1.000

0.962

1.165

$1.947^{* * *}$

$0.872 * *$

0.000

$-0.189$

$-0.452$

0.654

$-0.400$

0.039

0.075

0.095

0.036

1.000

$0.827^{* * *}$

$0.636^{* * *}$

$1.924 * * *$

$0.670^{* * *}$

0.058

0.000

0.203

0.113

0.056

0.062

Relative conditions of the address

to other residential properties

$$
\begin{array}{r}
\text { Better (ref) } \\
\text { About the same } \\
\text { Worse } \\
\text { Unable to obtain information }
\end{array}
$$

0.000

$-0.047$

0.054

$-0.202$

0.078

0.008

0.239

\section{Call Record Variables}

\section{Time of day call 1}

Morning (0.00-12.00) (ref)

Afternoon (12.00-17.00)

Evening (17.00-24.00)

Time of day call 2

$$
\text { Morning (0.00-12.00) (ref) }
$$

0.000

Afternoon (12.00-17.00)

$-0.064$

Evening (17.00-24.00)

$-0.102$

Time of day call 3

Morning (0.00-12.00) (ref)

$$
\begin{gathered}
\text { Afternoon (12.00-17.00) } \\
\text { Evening (17.00-24.00) }
\end{gathered}
$$

Time between call 1 and call 2

-0.015
-0.094

0.039

0.041

0.026

0.002

Time between call 2 and call 3

0.030

0.001

1.000
1.013
$1.193^{* *}$

$1.232^{* *}$
1.060

1.000
$1.225^{* * *}$
1.120

1.120

1.000
0.954
$0.903^{*}$
1.008

0.000

$-0.242$

$-0.440$

$-1.248$

0.053

0.074

0.260

1.000

0.906

$0.762 * * *$

$0.849 *$

$0.732 * * *$

$\begin{array}{lll}0.000 & & 1.000 \\ 0.010 & 0.036 & 1.011 \\ -0.130 & 0.050 & 0.878^{* *}\end{array}$

1.000

0.937

0.903*
1.000

$0.785^{* * *}$

$0.644 * * *$

$0.287 * * *$

$0.878^{* *}$

\section{Call 1 outcome}




\begin{tabular}{rrrrllll} 
& No contact (ref) & 0.000 & & 1.000 & 0.000 & & 1.000 \\
Contact made & 0.081 & 0.037 & $1.085^{*}$ & -0.098 & 0.037 & $0.907^{* *}$ \\
& & & & & & & \\
Appointment made & 0.025 & 0.069 & 1.026 & 0.242 & 0.065 & $1.274^{* * *}$ \\
& Any other status & 0.124 & 0.095 & 1.133 & -0.035 & 0.096 & 0.966 \\
& Interview done & 1.022 & 0.240 & $2.780^{* * *}$ & 0.372 & 0.207 & 1.450 \\
& & & & & & \\
Call 2 outcome & & & & & \\
& No contact (ref) & 0.000 & & 1.000 & 0.000 & & 1.000 \\
Contact made & 0.095 & 0.038 & $1.099^{*}$ & -0.062 & 0.037 & 0.940 \\
& & & & & & \\
& Appointment made & 0.205 & 0.063 & $1.228^{* *}$ & 0.458 & 0.062 & $1.581^{* * *}$ \\
& Any other status & 0.293 & 0.088 & $1.340^{* *}$ & -0.024 & 0.092 & 0.977 \\
Interview done & 1.539 & 0.143 & $4.662^{* * *}$ & 0.517 & 0.116 & $1.677^{* * *}$ \\
& & & & & & \\
& No contact (ref) & 0.000 & & 1.000 & 0.000 & & 1.000 \\
Contact made & 0.499 & 0.037 & $1.645^{* * *}$ & -0.148 & 0.037 & $0.862^{* * *}$ \\
& & & & & & \\
& Appointment made & 2.000 & 0.048 & $7.389^{* * *}$ & 2.024 & 0.053 & $7.568^{* * *}$ \\
& Any other status & 1.227 & 0.065 & $3.410^{* * *}$ & -1.185 & 0.074 & $0.305^{* * *}$ \\
Interview done & 2.352 & 0.110 & $10.511^{* * *}$ & 0.860 & 0.087 & $2,364^{* * *}$ \\
\hline
\end{tabular}

${ }^{* * *} \mathrm{p}<0.001 ;{ }^{* *} \mathrm{p}<0.01 ;{ }^{*} \mathrm{p}<0.05 ;$ ref - reference category

In the model for final outcome some of the same variables are significant as in the model for length, however, sometimes with the opposite effect. For example, the odds of having a successful call sequence are lower across all regions, in particular for London and the SouthEast, when compared to North East. Households with no children are significantly less likely to respond and a longer time in between calls is associated with a reduced likelihood of response. A contact in any of the previous calls is associated with a higher likelihood of non-response as is any other status. Appointment made and any interviewing performed increases the likelihood of a successful call sequence as one would expect. The effect of number of floors and the presence of cars/vans are in the same direction as for length of call sequence.

Table 6 presents estimated coefficients for the multinomial model. To ease interpretation predicted probabilities are computed for selected explanatory variables (Figure 1) holding 
constant all other variables at their mean value. Variables from each of the three groups of explanatory variables are chosen: geographic (region), interviewer observations (accommodation type) and call record variables (time of day of first call, third call outcome). Figure 1a suggests that the probability of having long unsuccessful sequences is the highest in London followed by Scotland and East of England. It is also highest in flats compared to other types of accommodation with short successful calls highest in detached houses (Figure 1b). Figure 1c suggests that conducting the first call in the evening is associated with a higher probability of a long unsuccessful call sequence. (Researchers need to be cautious in interpreting this as a causal effect since interviewers may have reasons for calling in the evening, even at the first call). Figure 1d indicates a marked difference between call outcomes, with the likelihood for short successful call sequences clearly highest if the third call is an appointment or an interview. Long unsuccessful call sequences are associated with non-contacts and to a slightly lesser extent with contact. The likelihood of having a short unsuccessful sequence is clearly highest when the third call attempt is recorded as being 'any other status'. 
Table 6: Estimated coefficients for the multinomial regression model for the combined dependent variable (length and final outcome) including geographic and design variables, interviewer observation variables and call record variables comprising timing and outcome of the call(s) (Model 6).

\begin{tabular}{|c|c|c|c|c|c|c|}
\hline \multirow[b]{2}{*}{ Variable } & \multicolumn{2}{|c|}{ Short Unsuccessful } & \multicolumn{2}{|c|}{ Short Successful } & \multicolumn{2}{|c|}{ Long Successful } \\
\hline & $\bar{\beta}$ & Robust SE & $\beta$ & Robust SE & $\bar{\beta}$ & Robust SE \\
\hline Constant & $-1.832 * * *$ & 0.216 & $-0.396 *$ & 0.192 & -0.018 & 0.198 \\
\hline $\begin{array}{l}\text { Geographic and } \\
\text { design variables } \\
\text { Months }\end{array}$ & & & & & & \\
\hline $\begin{array}{r}\text { January-June year } 1 \\
\text { (ref) }\end{array}$ & 0.000 & & 0.000 & & 0.000 & \\
\hline $\begin{array}{r}\text { July-December } \\
\text { year } 1\end{array}$ & $-0.316^{* * *}$ & 0.058 & 0.060 & 0.051 & 0.032 & 0.055 \\
\hline January-June year 2 & $-0.354^{* * *}$ & 0.055 & $-0.157 * *$ & 0.051 & -0.071 & 0.054 \\
\hline $\begin{array}{r}\text { July-December } \\
\text { year } 2\end{array}$ & $-0.424 * * *$ & 0.055 & $-0.237 * * *$ & 0.051 & -0.001 & 0.053 \\
\hline \multicolumn{7}{|l|}{ Government } \\
\hline \multicolumn{7}{|l|}{$\begin{array}{l}\text { Office Region } \\
\text { (GOR) }\end{array}$} \\
\hline North East (ref) & 0.000 & & 0.000 & & 0.000 & \\
\hline North West & 0.020 & 0.112 & -0.049 & 0.101 & $-0.259 *$ & 0.101 \\
\hline $\begin{array}{r}\text { Yorkshire and the } \\
\text { Humber }\end{array}$ & 0.168 & 0.116 & -0.029 & 0.105 & -0.212 & 0.107 \\
\hline East Midlands & -0.040 & 0.122 & 0.105 & 0.109 & 0.047 & 0.110 \\
\hline West Midlands & 0.065 & 0.114 & -0.137 & 0.104 & $-0.305^{* *}$ & 0.104 \\
\hline East of England & -0.130 & 0.114 & -0.149 & 0.102 & $-0.358 * *$ & 0.104 \\
\hline London & $-0.323 * *$ & 0.111 & $-0.591 * * *$ & 0.100 & $-0.439 * * *$ & 0.098 \\
\hline South East & 0.123 & 0.108 & -0.168 & 0.098 & $-0.245^{*}$ & 0.098 \\
\hline South West & 0.195 & 0.118 & 0.046 & 0.106 & $-0.337 * *$ & 0.110 \\
\hline Wales & $0.271^{*}$ & 0.133 & -0.007 & 0.120 & -0.125 & 0.122 \\
\hline Scotland & $0.389 * *$ & 0.117 & -0.143 & 0.107 & $-0.280 * *$ & 0.107 \\
\hline \multicolumn{7}{|l|}{ Urban/rural } \\
\hline Urban area (ref) & 0.000 & & 0.000 & & 0.000 & \\
\hline Rural area & $0.183^{* *}$ & 0.054 & $0.136^{* *}$ & 0.050 & 0.015 & 0.057 \\
\hline \multicolumn{7}{|c|}{$\begin{array}{l}\text { Interviewer } \\
\text { observations } \\
\text { variables }\end{array}$} \\
\hline Not mentioned (ref) & 0.000 & & 0.000 & & 0.000 & \\
\hline Mentioned & -0.025 & 0.151 & $-0.515^{* * *}$ & 0.147 & -0.147 & 0.141 \\
\hline Accommodation & & & & & & \\
\hline $\begin{array}{r}\text { Detached } \\
\text { house/bungalow } \\
\text { (ref) }\end{array}$ & 0.000 & & 0.000 & & 0.000 & \\
\hline $\begin{array}{l}\text { Semi-detached } \\
\text { house/bungalow }\end{array}$ & -0.073 & 0.059 & -0.072 & 0.054 & -0.011 & 0.060 \\
\hline $\begin{array}{r}\text { Terraced house/end } \\
\text { terraced } \\
\text { house/bungalow }\end{array}$ & $-0.320 * * *$ & 0.066 & -0.101 & 0.059 & 0.089 & 0.064 \\
\hline $\begin{array}{l}\text { Flats/maisonettes } \\
\text { purpose built or }\end{array}$ & $-0.604 * * *$ & 0.086 & -0.147 & 0.077 & -0.111 & 0.082 \\
\hline
\end{tabular}




\begin{tabular}{|c|c|c|c|c|c|c|}
\hline $\begin{array}{r}\text { converted } \\
\text { Bedsitters, } \\
\text { dwellings with } \\
\text { business and } \\
\text { sheltered } \\
\text { accommodation }\end{array}$ & 0.363 & 0.242 & 0.268 & 0.237 & 0.163 & 0.266 \\
\hline \multicolumn{7}{|l|}{ Floor } \\
\hline 0 floors & $0.997 * *$ & 0.342 & $1.343^{* * *}$ & 0.317 & $1.084^{* *}$ & 0.350 \\
\hline 1 floor & $0.248^{*}$ & 0.111 & $0.524 * * *$ & 0.101 & $0.366^{* * *}$ & 0.104 \\
\hline 2 floors & 0.135 & 0.107 & $0.383 * * *$ & 0.097 & $0.349 * * *$ & 0.098 \\
\hline 3 floors & -0.092 & 0.114 & $0.311^{* *}$ & 0.102 & $0.394 * * *$ & 0.100 \\
\hline $\begin{array}{r}4 \text { floors and above } \\
\text { (ref) }\end{array}$ & 0.000 & & 0.000 & & 0.000 & \\
\hline \multicolumn{7}{|l|}{ Car/van } \\
\hline $\begin{array}{r}\text { Definitely has a } \\
\text { car/van (ref) }\end{array}$ & 0.000 & & 0.000 & & 0.000 & \\
\hline Likely & 0.067 & 0.058 & $-0.206^{* * *}$ & 0.052 & $-0.147 * *$ & 0.056 \\
\hline Unlikely & $0.329 * *$ & 0.105 & $-0.271 * *$ & 0.101 & $-0.500 * * *$ & 0.110 \\
\hline $\begin{array}{r}\text { Definitely does not } \\
\text { have a car/van }\end{array}$ & $0.838 * * *$ & 0.157 & $1.101^{* * *}$ & 0.133 & $-0.746 * * *$ & 0.138 \\
\hline $\begin{array}{r}\text { Cannot tell from } \\
\text { observation }\end{array}$ & 0.043 & 0.058 & $-0.468 * * *$ & 0.053 & $0.328 * * *$ & 0.055 \\
\hline \multicolumn{7}{|l|}{ Child } \\
\hline $\begin{array}{r}\text { Definitely has a } \\
\text { child/children aged } \\
\text { under } 10 \text { (ref) }\end{array}$ & 0.000 & & 0.000 & & 0.000 & \\
\hline Likely & -0.056 & 0.115 & -0.055 & 0.096 & -0.162 & 0.098 \\
\hline Unlikely & $0.237 *$ & 0.099 & -0.068 & 0.084 & $-0.330 * * *$ & 0.086 \\
\hline $\begin{array}{r}\text { Definitely does not } \\
\text { have a } \\
\text { child/children aged } \\
\text { under } 10\end{array}$ & $0.314^{* *}$ & 0.102 & 0.029 & 0.086 & -0.164 & 0.087 \\
\hline $\begin{array}{r}\text { Cannot tell from } \\
\text { observation }\end{array}$ & 0.095 & 0.079 & $-0.185^{*}$ & 0.079 & $-0.370 * * *$ & 0.080 \\
\hline \multicolumn{7}{|l|}{ Unkempt garden } \\
\hline Yes (ref) & 0.000 & & 0.000 & & 0.000 & \\
\hline No & $0.311^{* * *}$ & 0.077 & $0.200 * *$ & 0.072 & 0.094 & 0.071 \\
\hline No obvious garden & $0.212 *$ & 0.085 & 0.071 & 0.079 & 0.047 & 0.077 \\
\hline \multicolumn{7}{|c|}{$\begin{array}{l}\text { Relative } \\
\text { conditions of the } \\
\text { address to other } \\
\text { residential } \\
\text { properties }\end{array}$} \\
\hline Better (ref) & 0.000 & & 0.000 & & 0.000 & \\
\hline About the same & 0.093 & 0.079 & $-0.255^{* * *}$ & 0.067 & $-0.162 *$ & 0.073 \\
\hline Worse & 0.014 & 0.110 & $-0.525 * * *$ & 0.101 & $-0.288 * *$ & 0.105 \\
\hline $\begin{array}{l}\text { Unable to obtain } \\
\text { information }\end{array}$ & 0.337 & 0.313 & $-0.872^{* *}$ & 0.311 & $-1.540^{* *}$ & 0.480 \\
\hline $\begin{array}{l}\text { Call Record } \\
\text { Variables }\end{array}$ & & & & & & \\
\hline $\begin{array}{r}\text { Morning (0.00- } \\
12.00) \text { (ref) }\end{array}$ & 0.000 & & 0.000 & & 0.000 & \\
\hline $\begin{array}{r}\text { Afternoon (12.00- } \\
17.00)\end{array}$ & 0.018 & 0.052 & 0.034 & 0.047 & -0.021 & 0.049 \\
\hline Evening (17.00- & -0.081 & 0.071 & $-0.180 * *$ & 0.065 & -0.119 & 0.067 \\
\hline
\end{tabular}




\begin{tabular}{|c|c|c|c|c|c|c|}
\hline \multicolumn{7}{|l|}{$24.00)$} \\
\hline Time of day call 2 & & & & & & \\
\hline $\begin{array}{r}\text { Morning (0.00- } \\
12.00) \text { (ref) }\end{array}$ & 0.000 & & 0.000 & & 0.000 & \\
\hline $\begin{array}{r}\text { Afternoon (12.00- } \\
17.00)\end{array}$ & -0.023 & 0.053 & -0.012 & 0.048 & $0.141^{* *}$ & 0.052 \\
\hline $\begin{array}{r}\text { Evening (17.00- } \\
24.00)\end{array}$ & $-0.126 *$ & 0.059 & -0.072 & 0.054 & 0.011 & 0.059 \\
\hline \multicolumn{7}{|l|}{ Time of day call 3} \\
\hline $\begin{array}{r}\text { Morning }(0.00- \\
12.00) \text { (ref) }\end{array}$ & 0.000 & & 0.000 & & 0.000 & \\
\hline $\begin{array}{r}\text { Afternoon (12.00- } \\
17.00)\end{array}$ & -0.025 & 0.054 & 0.028 & 0.050 & 0.058 & 0.053 \\
\hline $\begin{array}{r}\text { Evening (17.00- } \\
24.00)\end{array}$ & $-0.127 *$ & 0.057 & -0.083 & 0.052 & -0.034 & 0.055 \\
\hline $\begin{array}{l}\text { Time between call } \\
1 \text { and call } 2\end{array}$ & $0.034 * * *$ & 0.002 & -0.002 & 0.002 & $-0.024 * * *$ & 0.003 \\
\hline $\begin{array}{l}\text { Time between call } \\
2 \text { and call } 3\end{array}$ & $0.038 * * *$ & 0.002 & -0.001 & 0.002 & $-0.028 * * *$ & 0.003 \\
\hline \multicolumn{7}{|l|}{ Call 1 outcome } \\
\hline No contact (ref) & 0.000 & & 0.000 & & 0.000 & \\
\hline Contact made & $0.279 * * *$ & 0.050 & -0.038 & 0.048 & 0.035 & 0.052 \\
\hline Appointment made & 0.124 & 0.094 & $0.219 *$ & 0.088 & $0.337 * * *$ & 0.087 \\
\hline Any other status & $0.292 *$ & 0.118 & 0.055 & 0.130 & 0.138 & 0.145 \\
\hline Interview done & $1.510 * * *$ & 0.335 & $1.320 * * *$ & 0.327 & $0.821 *$ & 0.350 \\
\hline \multicolumn{7}{|l|}{ Call 2 outcome } \\
\hline No contact (ref) & 0.000 & & 0.000 & & 0.000 & \\
\hline Contact made & $0.198 * * *$ & 0.052 & 0.012 & 0.049 & -0.024 & 0.052 \\
\hline Appointment made & 0.032 & 0.089 & $0.516^{* * *}$ & 0.081 & $0.316^{* * *}$ & 0.086 \\
\hline Any other status & $0.436 * * *$ & 0.107 & 0.202 & 0.124 & 0.228 & 0.147 \\
\hline Interview done & 2.056 & 0.221 & $2.043 * * *$ & 0.210 & $1.012^{* * *}$ & 0.238 \\
\hline \multicolumn{7}{|l|}{ Call 3 outcome } \\
\hline No contact (ref) & 0.000 & & 0.000 & & 0.000 & \\
\hline Contact made & $0.618 * * *$ & 0.050 & $0.273^{* * *}$ & 0.049 & $-0.203 * * *$ & 0.052 \\
\hline Appointment made & 0.187 & 0.102 & $2.683 * * *$ & 0.063 & $0.568 * * *$ & 0.080 \\
\hline Any other status & $1.780 * * *$ & 0.077 & -0.125 & 0.102 & $-0.661 * * *$ & 0.119 \\
\hline Interview done & $2.344 * * *$ & 0.169 & $2.704^{* * *}$ & 0.157 & $0.556^{* *}$ & 0.195 \\
\hline
\end{tabular}

$* * * \mathrm{p}<0.001 ;{ }^{* *} \mathrm{p}<0.01 ;{ }^{*} \mathrm{p}<0.05$; ref - reference category.

Reference category for the response variable is Long Unsuccessful. 
Figure 1: Predicted probabilities for the final combined model (final outcome and length) for selected explanatory variables (at least one variable from each group of explanatory variables in Model 6)

a.)

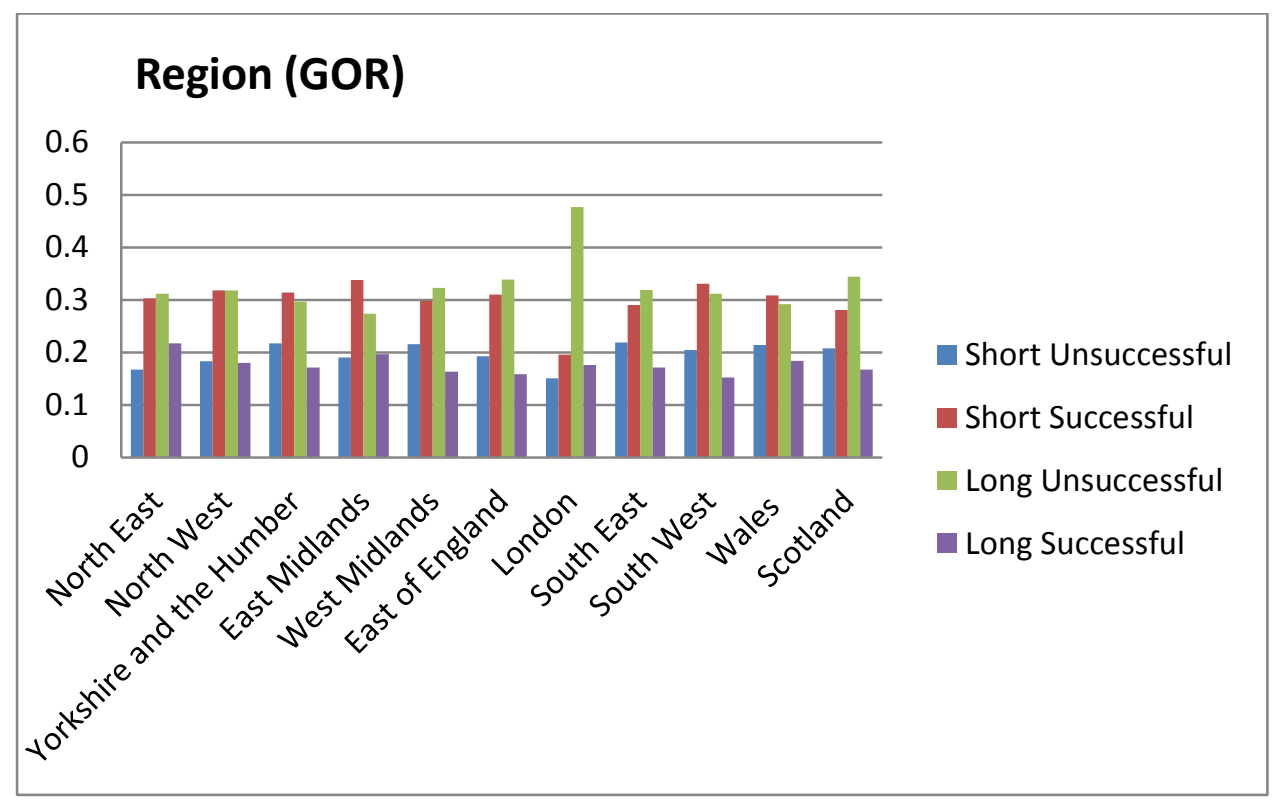

b.)

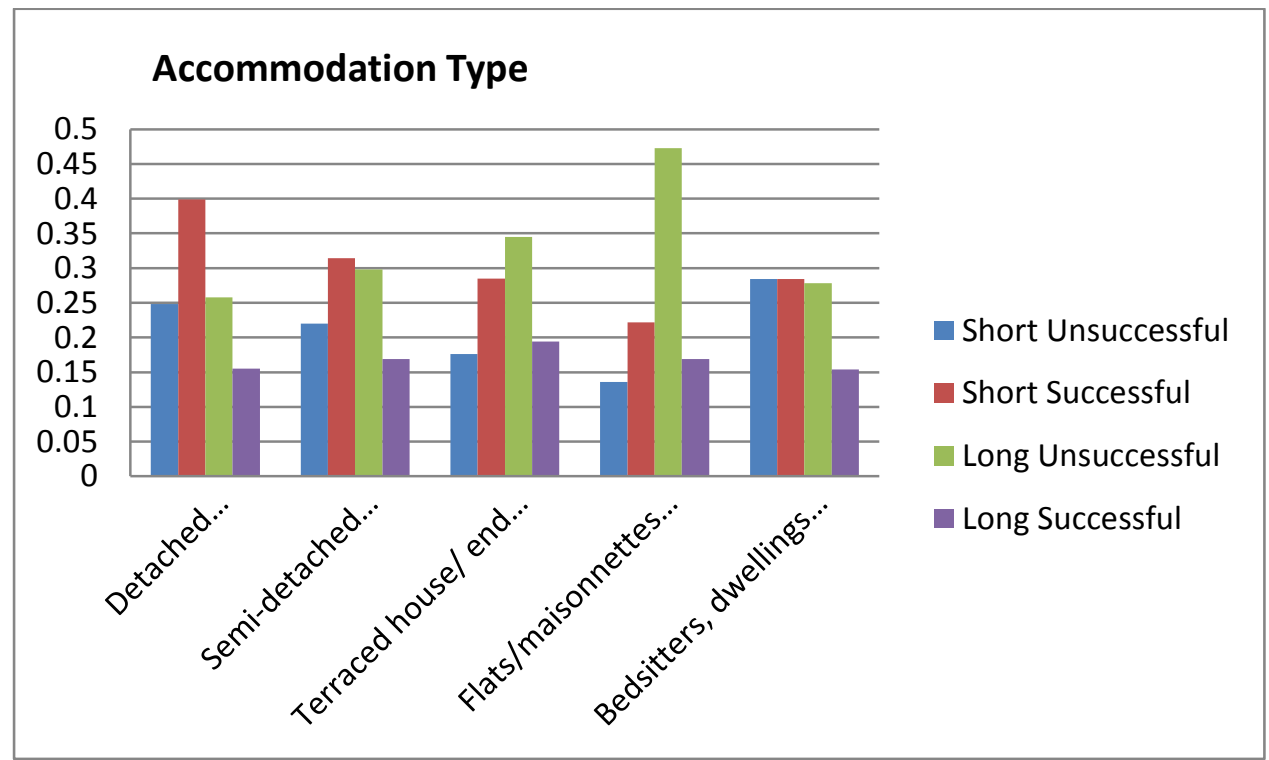


c.)

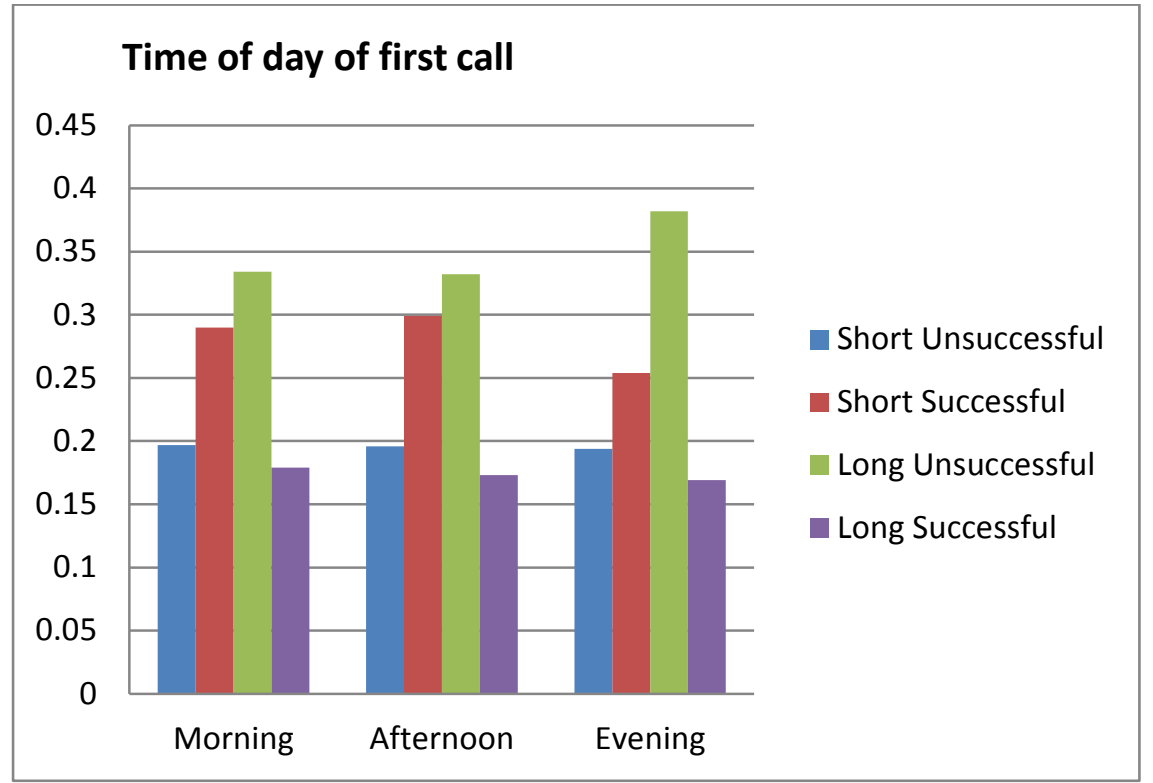

d.)

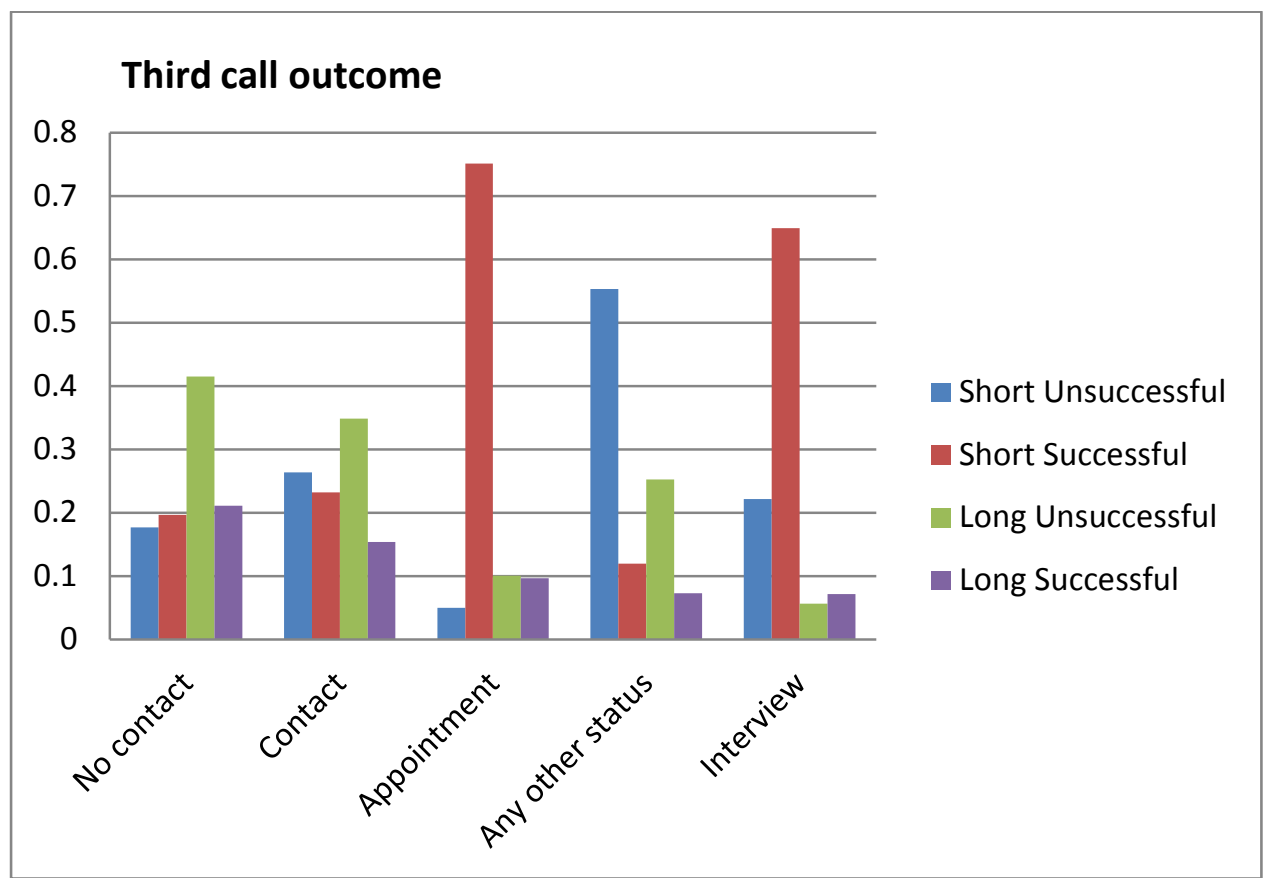




\section{Conclusions and implications for survey practice}

This paper presents an example of how to use paradata for interviewer-administered surveys, a topic often discussed in the literature. The paper employs a range of interviewer observation and call record variables to predict both final outcome and length of a call sequence early on in the data collection process. Models are developed prior to data collection and after the first, second and third call respectively to see if predictions of the models improve once more and more call record data are available. The models are developed both separately and jointly for the two outcomes of interest. The research was motivated by a recent sequence analysis (Durrant et al. 2014) which identified a categorisation of sequences based on length and outcome. Survey researchers have focussed on predicting outcome, either final outcome or outcome at each call (Groves and Couper 1998; Durrant, D’Arrigo, and Steele 2013). Here, this is extended to also include length of call sequence, a variable that so far has only been considered as an explanatory variable in non-response models.

The key findings from this analysis are:

1. Modelling outcome and length of call sequence jointly improves the fit of the model in comparison to the two separate models based on the pseudo- $\mathrm{R}^{2}$ values and the classification tables.

2. The models proposed have the ability to predict the outcomes of interest reasonably well (length, final call outcome and the combined model) with a pseudo- $\mathrm{R}^{2}$ of around $26 \%$ for the binary cases and 36\% for the combined outcome. This is very high in a social science context and compares to values of around 3-8\% for non-response models in the literature (Olson, Smyth, and Wood 2012; Olson and Groves 2012; West and Groves 2013). Classification tables show about 70\% correctly classified cases for the binary cases 
(expected baseline is 50\%) and even 52\% for the multinomial case (expected baseline is $25 \%)$.

3. A number of variables are significant for both the model for length and the model for outcome. However, their effect may have opposite signs. For example, a household unlikely to have children has a higher probability of a shorter call sequence but a lower probability of response; a longer time in between calls may be associated with a shorter call sequence but with a lower probability of response.

4. Call record variables: The outcomes of previous calls, in particular the most recent call, are highly significant for both final response outcome and sequence length and their inclusion greatly improves the predictive power, with the $\mathrm{R}^{2}$ increasing from less than $9 \%$ to above $26 \%$. As one might expect, the prediction improves significantly when more and more call outcomes are available. We found evidence that it is the most recent call outcome that may have the biggest influence, rather than the first call, for example. We found some indication that entering the raw outcome variables from each call (i.e. outcome of call 1, 2 and 3) as opposed to entering a summary measure, such as total number of non-contacts, improves the fit slightly. Often discussed in the literature as important variables, controlling for timing of calls has less impact on the performance of the model $\left(\mathrm{R}^{2}\right)$, although some of these variables are significant predictors throughout. Time between calls was often highly significant. Time of day was either not significant or only marginally significant. Interestingly, the day of the week was not found to be significant in the majority of models.

5. Interviewer observation variables: A number of interviewer observation variables (such as floor, car/van, child, relative condition of property) are found to be significant in all models. However, their contribution to the improvement of the model prediction is limited having 
controlled for previous call outcome(s). Adding interviewer observation variables to a model with, for example, only basic geographical information doubles or even quadruples the $\mathrm{R}^{2}$ value.

6. Basic geographic information, available prior to the first call, are found to be significant variables for most models but are not found very effective in predicting final outcome and length of call sequence.

The findings highlight benefits and implications for survey practice, especially for adaptive and responsive survey designs, monitoring continually the streams of process data to alter the survey design during the course of data collection (Groves and Heeringa 2006). The paper proposes a methodology that can be used and adapted by survey managers of other datasets, for both cross-sectional and longitudinal surveys. First, we strongly encourage researchers to use sensitivity and the positive predicted value rather than just the $\mathrm{R}^{2}$ statistic to assess non-response models. The predictions from the two separate or the combined model provide one way of informing survey managers which households to follow up or where to stop calling. In this paper the focus is on efficiency to avoid very long call sequences. This guidance should, in practice, be supplemented with information about the impact of cases on nonresponse bias during data collection and further work in this area is currently being undertaken. Survey managers may wish to weigh up between the probability of a successful outcome versus sequence length. Ideally survey agencies may want to follow up those with potentially relatively short sequences and successful outcomes. Cases that are predicted to have long call sequences with many interviewer visits to a household may also be contacted by other means first (e.g. telephone) to avoid successive non-contacts at the doorstep. Often call record and interviewer observation 
variables can be supplemented further by additional linked datasources, such as from administrative or census data. Here, we only control for linked basic geographic information. Particular benefits of this work exist for data from longitudinal surveys since here the models can be, in principle, fitted for prediction in subsequent waves. Models may then be extended to include call record data and survey information from previous waves. Both of these further work strands are currently being explored.

The analysis indirectly assumes that all calls carry the same costs, e.g. staff and time resources and financial cost of a call. However, in practice some calls may be relatively inexpensive and may imply little extra burden, if, for example, a call can be made on the way to another household. The analysis could be extended to include such cost considerations. However, given the data we have available to us, we are unable to carry this out. The current work assumes a cut-off value $\pi_{0}$ to identify a household as a respondent or non-respondent based on their predicted probabilities. In practice, different values may be explored to optimise sensitivity and specificity in the specific survey setting considered. Other definitions of the dependent variables may also be considered (e.g. complete household response rather than 'at least one interview'). Due to the observational nature of the data we cannot establish causal links but merely associations between the response and the explanatory variables. However, this restriction is not a limitation as the main interest of the analysis is not to establish causal links but to compare performance of different models and to identify significant explanatory variables.

\section{References}

Agresti, A. (2013), Categorical Data Analysis (3rd edition), New Jersey: John Wiley \& Sons. Altman, D. G. (1991), Practical Statistics for Medical Research, London: Champan \& Hall. 
Bates, N., Dahlhamer, J., and Singer, E. (2008), “Privacy Concerns, Too Busy, or Just Not Interested: Using Doorstep Concerns to Predict Survey Nonresponse,” Journal of Official Statistics, 24, 591-612.

Durrant, G. B., D’Arrigo, J., and Müller, G. (2013), “Modeling Call Record Data: Examples from Cross-Sectional and Longitudinal Surveys,” in Improving Surveys with Paradata: Analytic Use of Process Information, ed. Kreuter, F., New Jersey: John Wiley and Sons, pp. 281-308.

Durrant, G.B., D’Arrigo, J., and Steele, F. (2011), "Using Field Process Data to Predict Best Times of Contact Conditioning on Household and Interviewer Influences,” Journal of the Royal Statistical Society, Series A, 174, 4, 1029-1049.

Durrant, G. B., D’Arrigo, J., and Steele, F. (2013), “Analysing Interviewer Call Record Data by Using a Multilevel Discrete-Time Event History Modelling Approach,” Journal of the Royal Statistical Society, Series A, Special issue: The Use of Paradata in Social Survey Research, 176, 1, 251-269.

Durrant, G. B., Maslovskaya, O., and Smith, P. W. F. (2014), "Sequence Analysis as a Tool for Investigating Call Record Data,” Working paper, University of Southampton.

Field, A. (2009), Discovering statistics using SPSS ( $3^{\text {rd }}$ edition), Los Angeles: SAGE.

Groves, R. M., and Couper, M. P. (1996), “Contact-level Influences on Cooperation in Face-toface Surveys,” Journal of Official Statistics, 12, 63-83.

Groves, R. M., and Couper, M. P. (1998), Nonresponse in Household Interview Surveys, New York: John Wiley and Sons. 
Groves, R. M., and Heeringa, S. G. (2006), “Responsive Design for Household Surveys: Tools for Actively Controlling Survey Errors and Costs,” Journal of the Royal Statistical Society, Series A, 169, 439-457.

Hanly, M. (2014), “Improving Nonresponse Bias Adjustments with Call Record Data,” Paper to be presented at 25th International Workshop on Household Survey Nonresponse, Iceland.

Huber, P. J. (1967), “The Behavior of Maximum Likelihood Estimates under Nonstandard Conditions,” in Proceedings of the Fifth Berkeley Symposium on Mathematical Statistics and Probability, Berkeley, CA: University of California Press, vol. 1, pp. 221-233.

Kreuter, F., and Kohler, U. (2009), “Analyzing Contact Sequences in Call Record Data. Potential and Limitations of Sequence Indicators for Nonresponse Adjustments in the European Social Survey,” Journal of Official Statistics, 25, 2, 203-226.

Kreuter, F., Olson, K., Wagner, J., Yan, T., Ezzati-Rice, T. M., Casas-Cordero, C., Lemay, M., Peytchev, A., Groves, R. M., and Raghunathan, T. E. (2010), “Using Proxy Measures and Other Correlates of Survey Outcomes to Adjust for Non-Response: Examples from Multiple Surveys,” Journal of the Royal Statistical Society, Series A, 173, 389-407.

Long, J. S., and Freese, J. (2006), Regression Models for Categorical Dependent Variables Using Stata $\left(2^{\text {nd }}\right.$ edition), Texas: STATA Press.

McFall, S. L. (ed.) (2012), Understanding Society: Findings 2012, Colchester: Institute for Social and Economic Research, University of Essex.

Olson, K., and Groves, R. M. (2012), “An Examination of Within-Person Variation in Response Propensity over the Data Collection Field Period,” Journal of Official Statistics, 28, 29-51. 
Olson, K., Smyth, J. D., and Wood, H. M. (2012), “Does Giving People Their Preferred Survey Mode Actually Increase Survey Participation Rates? An Experimental Examination,” Public Opinion Quarterly, 76, 611 - 635.

Pepe, M.S (2003), The Statistical Evaluation of Medical Tests for Classification and Prediction, Oxford: Oxford University Press.

Plewis, I., Ketende, S., and Calderwood, L. (2012), “Assessing the Accuracy of Response Propensities in Longitudinal Studies,” Survey Methodology, 38, 2, 167-171.

Potthoff, R. F., Manton, K. G., and Woodbury, M. A. (1993), “Correcting for Nonavailability Bias in Surveys by Weighting Based on Number of Callbacks,” Journal of the American Statistical Association, Applications and Case Studies, 88, 424, 1197-1207.

Sinibaldi, J. (2014), Evaluating the Quality of Interviewer Observed Paradata for Nonresponse Applications, PhD Thesis, München: Ludwig-Maximilian-Universität.

Sinibaldi, J., Durrant, G. B., and Kreuter, F. (2013), "Evaluating the Measurement Error of Interviewer Observed Paradata,” Public Opinion Quarterly, Special issue: Topics in Survey Measurement and Public Opinion, 77, 1, 173-193.

Sinibaldi, J., Trappmann, M., and Kreuter, F. (2014), "Which is the Better Investment for Nonresponse Adjustment: Purchasing Commercial Auxiliary Data or Collecting Interviewer Observations?” Public Opinion Quarterly (forthcoming).

Wagner, J. (2013a), “Adaptive Contact Strategies in Telephone and Face-to-Face Surveys,” Survey Research Methods, 7, 1, 45-55.

Wagner, J. (2013b), “Using Paradata-Driven Models to Improve Contact Rates in Telephone and Face-to-Face Surveys," in Improving Surveys with Paradata: Analytic Use of Process Information, ed. Kreuter, F., New Jersey: John Wiley and Sons, pp. 145-170. 
West, B. T., and Groves, R. M. (2013), “A Propensity-Adjusted Interviewer Performance Indicator,” Public Opinion Quarterly, 77, 352-74.

White, H. (1980), “A Heteroskedasticity-consistent Covariance Matrix Estimator and a Direct Test for Heteroskedasticity,” Econometrica, 48, 817-830.

White, H. (1984), Asymptotic Theory for Econometricians, Orlando, FL: Academic Press.

White, H. (1994), Estimation, Inference and Specification Analysis, New York: Cambridge University Press. 


\section{Online Appendix}

Table A1: Exact wording of all variables used in the analysis

\begin{tabular}{|c|c|}
\hline Variable & Question \\
\hline \multicolumn{2}{|c|}{ Used in the final models } \\
\hline Months & Month of sample issue \\
\hline Low density area for ethnic minorities & Low density area for ethnic minorities \\
\hline Government Office Region (GOR) & $\begin{array}{l}\text { Government Office Region of the } \\
\text { address }\end{array}$ \\
\hline Urban/rural & $\begin{array}{l}\text { Is the address located in urban or rural } \\
\text { area? }\end{array}$ \\
\hline Barrier 2 & $\begin{array}{l}\text { Are any of these physical barriers to } \\
\text { entry present at the address? Locked } \\
\text { gates }\end{array}$ \\
\hline Accommodation & Address dwelling type code \\
\hline Floor & $\begin{array}{l}\text { How many floors are there at the } \\
\text { address? }\end{array}$ \\
\hline Car/van & $\begin{array}{l}\text { Based on your observation, is it likely } \\
\text { that this address has a car or van? }\end{array}$ \\
\hline Child & $\begin{array}{l}\text { Based on your observation, is it likely } \\
\text { that this address contains one or more } \\
\text { children aged under } 10 \text { including babies? }\end{array}$ \\
\hline Unkempt garden & $\begin{array}{l}\text { Does the address have an unkempt } \\
\text { garden? }\end{array}$ \\
\hline $\begin{array}{l}\text { Relative conditions of the address to other } \\
\text { residential properties }\end{array}$ & $\begin{array}{l}\text { How is the external condition of the } \\
\text { address relative to other residential } \\
\text { properties in the area? }\end{array}$ \\
\hline Time of day call 1 & Time call started \\
\hline Time of day call 2 & Time call started \\
\hline Time of day call 3 & Time call started \\
\hline Call 1 outcome & Call status \\
\hline Call 2 outcome & Call status \\
\hline Call 3 outcome & Call status \\
\hline
\end{tabular}

Barrier 1

Barrier 3

Barrier 4

Vicinity 1

\section{Used for modelling but not significant in final models}

Are any of these physical barriers to entry present at the address? Locked common entrance

Are any of these physical barriers to entry present at the address? Security staff or gatekeeper

Are any of these physical barriers to entry present at the address? Entry phone access

Are any of the following present or 
Vicinity 2

Vicinity 3

Conditions of residential property

Start day 1

Start day 2

Start day 3

Start month 1

Start month 2

Start month 3

Start year 1

Start year 2

Start year 3 within sight or hearing of the address?

Boarded houses, abandoned buildings, demolished houses or demolished buildings

Are any of the following present or within sight or hearing of the address?

Trash, litter or junk in street/road Are any of the following present or within sight or hearing of the address? Heavy traffic on street/road Which of these best describes the condition of residential properties in the area?

Day call started

Day call started

Day call started

Month call started

Month call started

Month call started

Year call started

Year call started

Year call started

Table A2: Distribution of explanatory variables by the dependent variables (a.) for length and final outcome and b.) for the combined dependent variable of length and outcome).

a.)

\begin{tabular}{|c|c|c|c|c|}
\hline \multirow[b]{2}{*}{ Variables } & \multicolumn{2}{|c|}{ Length } & \multicolumn{2}{|c|}{ (Final) Outcome } \\
\hline & $\begin{array}{c}\text { Short } \\
\text { (up to } 6 \text { calls) }\end{array}$ & $\begin{array}{l}\text { Long (more } \\
\text { than } 6 \text { calls) }\end{array}$ & $\begin{array}{l}\text { No interviews } \\
\text { after call } 3\end{array}$ & $\begin{array}{c}\text { At least one } \\
\text { interview after } \\
\text { call } 3\end{array}$ \\
\hline $\begin{array}{l}\text { Geographic and } \\
\text { design } \\
\text { Months }\end{array}$ & & & & \\
\hline $\begin{array}{r}\text { January-June year } \\
1\end{array}$ & 3,209 (51.3\%) & $3,044(48.7 \%)$ & $3,253(52.0 \%)$ & $3,000(48.0 \%)$ \\
\hline $\begin{array}{r}\text { July-December } \\
\text { year } 1\end{array}$ & 2,897 (49.6\%) & $2,946(50.4 \%)$ & $2,978(51.0 \%)$ & 2,865 (49.0\%) \\
\hline January-June year 2 & 3,095 (47.9\%) & $3,371(52.1 \%)$ & 3,537 (54.7\%) & 2,929 (45.3\%) \\
\hline $\begin{array}{r}\text { July-December } \\
\text { year } 2\end{array}$ & $3,152(46.4 \%)$ & $3,644(53.6 \%)$ & 3,797 (55.9\%) & 2,999 (44.1\%) \\
\hline $\begin{array}{l}\text { Low density } \\
\text { area for ethnic }\end{array}$ & & & & \\
\hline
\end{tabular}




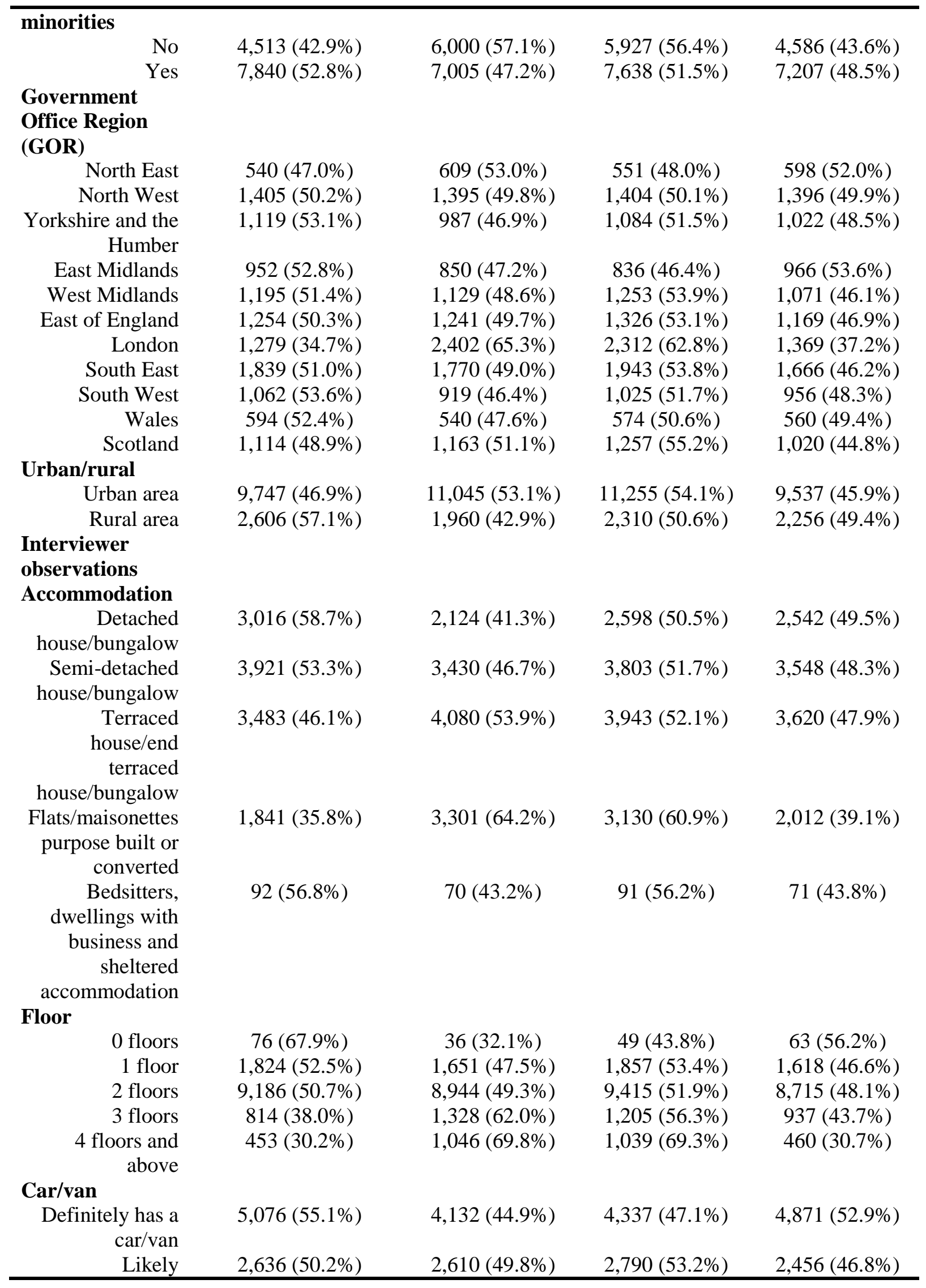




\begin{tabular}{|c|c|c|c|c|}
\hline Unlikely & 527 (50.5\%) & $516(49.5 \%)$ & 647 (62.0\%) & $396(38.0 \%)$ \\
\hline $\begin{array}{r}\text { Definitely does } \\
\text { not have a } \\
\text { car/van }\end{array}$ & 417 (62.2\%) & 253 (37.8\%) & 206 (30.7\%) & 464 (69.3\%) \\
\hline $\begin{array}{r}\text { Cannot tell from } \\
\text { observation }\end{array}$ & 3,697 (40.2\%) & 5,494 (59.8\%) & 5,585 (60.8\%) & 3,606 (39.2\%) \\
\hline \multicolumn{5}{|l|}{ Child } \\
\hline $\begin{array}{r}\text { Definitely has a } \\
\text { child/children } \\
\text { aged under } 10\end{array}$ & 853 (51.3\%) & $811(48.7 \%)$ & $693(41.6 \%)$ & 971 (58.4\%) \\
\hline Likely & 1,128 (51.2\%) & 1,073 (48.8\%) & 1,008 (45.8\%) & $1,193(54.2 \%)$ \\
\hline Unlikely & $2,630(51.0 \%)$ & 2,522 (49.0\%) & 2,866 (55.6\%) & $2,286(44.4 \%)$ \\
\hline $\begin{array}{r}\text { Definitely does } \\
\text { not have a } \\
\text { child/children } \\
\text { aged under } 10\end{array}$ & 2,133 (54.9\%) & 1,755 (45.1\%) & 1,864 (47.9\%) & $2,024(52.1 \%)$ \\
\hline $\begin{array}{r}\text { Cannot tell from } \\
\text { observation }\end{array}$ & 5,609 (45.0\%) & 6,844 (55.0\%) & 7,134 (57.3\%) & 5,319 (42.7\%) \\
\hline \multicolumn{5}{|l|}{ Unkempt garden } \\
\hline Yes & 1,001 (42.9\%) & 1,335 (57.1\%) & 1,249 (53.5\%) & 1,087 (46.5\%) \\
\hline No & 9,007 (52.6\%) & 8,121 (47.4\%) & 8,891 (51.9\%) & 8,237 (48.1\%) \\
\hline $\begin{array}{r}\text { No obvious } \\
\text { garden }\end{array}$ & 2,345 (39.8\%) & 3,549 (60.2\%) & 3,425 (58.1\%) & 2,469 (41.9\%) \\
\hline \multicolumn{5}{|l|}{$\begin{array}{l}\text { Relative } \\
\text { conditions of the } \\
\text { address to other } \\
\text { residential } \\
\text { properties }\end{array}$} \\
\hline Better & $1,054(53.5 \%)$ & 917 (46.5\%) & 912 (46.3\%) & 1,059 (53.7\%) \\
\hline About the same & 10,517 (48.9\%) & 10,981 (51.5\%) & $11,529(53.6 \%)$ & 9,969 (46.4\%) \\
\hline Worse & 743 (41.4\%) & $1,050(58.6 \%)$ & 1,047 (58.4\%) & 746 (41.6\%) \\
\hline $\begin{array}{l}\text { Unable to obtain } \\
\text { information }\end{array}$ & 39 (40.6\%) & 57 (59.4\%) & 77 (80.2\%) & 19 (19.8\%) \\
\hline \multicolumn{5}{|l|}{$\begin{array}{l}\text { Call Record } \\
\text { Variables } \\
\text { Time of day call } \\
1\end{array}$} \\
\hline $\begin{array}{r}\text { Morning (0- } \\
12.00)\end{array}$ & 2,280 (48.7\%) & 2,402 (51.3\%) & 2,485 (53.1\%) & 2,197 (46.9\%) \\
\hline $\begin{array}{r}\text { Afternoon (12.00- } \\
17.00)\end{array}$ & 8,485 (49.5\%) & 8,647 (50.5\%) & 9,037 (52.7\%) & 8,095 (47.3\%) \\
\hline $\begin{array}{r}\text { Evening (17.00- } \\
\text { 24.00) }\end{array}$ & 1,588 (44.8\%) & 1,956 (55.2\%) & 2,043 (57.6\%) & $1,501(42.4 \%)$ \\
\hline \multicolumn{5}{|l|}{$\begin{array}{l}\text { Time of day call } \\
2\end{array}$} \\
\hline $\begin{array}{r}\text { Morning (0- } \\
12.00)\end{array}$ & 2,377 (50.7\%) & 2,314 (49.3\%) & 2,524 (53.8\%) & 2,167 (46.2\%) \\
\hline $\begin{array}{r}\text { Afternoon (12.00- } \\
17.00)\end{array}$ & 6,653 (48.7\%) & 7,016 (51.3\%) & 7,198 (52.7\%) & 6,471 (47.3\%) \\
\hline $\begin{array}{r}\text { Evening (17.00- } \\
24.00) \\
\end{array}$ & 3,323 (47.5\%) & 3,675 (52.5\%) & 3,843 (54.9\%) & 3,155 (45.1\%) \\
\hline
\end{tabular}




\begin{tabular}{|c|c|c|c|c|}
\hline \multicolumn{5}{|l|}{$\begin{array}{l}\text { Time between } \\
\text { call } 1 \text { and call } 2 \\
\text { Time of day call } \\
3\end{array}$} \\
\hline Morning(0-12.00) & 2,346 (50.4\%) & 2,313 (49.6\%) & 2,515 (54.0\%) & 2,144 (46.0\%) \\
\hline $\begin{array}{r}\text { Afternoon (12.00- } \\
17.00)\end{array}$ & $5,801(49.3 \%)$ & $5,974(50.7 \%)$ & $6,325(53.7 \%)$ & $5,450(46.3 \%)$ \\
\hline $\begin{array}{r}\text { Evening (17.00- } \\
24.00)\end{array}$ & 4,206 (47.1\%) & 4,718 (52.9\%) & 4,725 (52.9\%) & 4,199 (47.1\%) \\
\hline \multicolumn{5}{|l|}{$\begin{array}{l}\text { Time between } \\
\text { call } 2 \text { and call } 3 \\
\text { Call } 1 \text { outcome }\end{array}$} \\
\hline No contact & 7,876 (45.0\%) & 9,640 (55.0\%) & 9,135 (52.2\%) & 8,381 (47.8\%) \\
\hline Contact made & 2,957 (55.4\%) & 2,385 (44.6\%) & 3,136 (58.7\%) & 2,206 (41.3\%) \\
\hline $\begin{array}{r}\text { Appointment } \\
\text { made }\end{array}$ & 909 (58.1\%) & 655 (41.9\%) & $680(43.5 \%)$ & 884 (56.5\%) \\
\hline Any other status & $521(64.2 \%)$ & 291 (35.8\%) & 564 (69.5\%) & 248 (30.5\%) \\
\hline Interview done & $90(72.6 \%)$ & $34(27.4 \%)$ & $50(40.3 \%)$ & 74 (59.7\%) \\
\hline \multicolumn{5}{|l|}{ Call 2 outcome } \\
\hline No contact & 7,225 (43.2\%) & 9,513 (56.8\%) & 8,900 (53.2\%) & 7,838 (46.8\%) \\
\hline Contact made & 2,695 (53.2\%) & $2,372(46.8 \%)$ & $2,909(57.4 \%)$ & $2,158(42.6 \%)$ \\
\hline $\begin{array}{r}\text { Appointment } \\
\text { made }\end{array}$ & $1,215(62.7 \%)$ & $722(37.3 \%)$ & $750(38.7 \%)$ & 1187 (61.3\%) \\
\hline Any other status & 808 (71.8\%) & 317 (28.2\%) & 843 (74.9\%) & 282 (25.1\%) \\
\hline Interview done & $410(83.5 \%)$ & $81(16.5 \%)$ & $163(33.2 \%)$ & 328 (66.8\%) \\
\hline \multicolumn{5}{|l|}{ Call 3 outcome } \\
\hline No contact & 5,706 (37.4\%) & 9,547 (62.6\%) & 9,034 (59.2\%) & 6,219 (40.8\%) \\
\hline Contact made & $2,196(49.6 \%)$ & $2,230(50.4 \%)$ & 2,717 (61.4\%) & 1,709 (38.6\%) \\
\hline $\begin{array}{r}\text { Appointment } \\
\text { made or interview } \\
\text { or complete }\end{array}$ & $2,793(80.1 \%)$ & $692(19.9 \%)$ & $528(15.2 \%)$ & 2,957 (84.8\%) \\
\hline Any other status & 860 (67.3\%) & 418 (32.7\%) & $1,031(80.7 \%)$ & 247 (19.3\%) \\
\hline Interview done & 798 (87.1\%) & $118(12.9 \%)$ & $2557.8 \%)$ & $\begin{array}{c}661 \\
(72.2 \%)\end{array}$ \\
\hline
\end{tabular}

b.)

\begin{tabular}{lcccc}
\hline \multicolumn{1}{c}{ Variables } & $\begin{array}{c}\text { Short } \\
\text { Unsuccessful }\end{array}$ & Short Successful & $\begin{array}{c}\text { Long } \\
\text { Unsuccessful }\end{array}$ & Long Successful \\
\hline $\begin{array}{l}\text { Geographic and } \\
\text { design } \\
\text { Months }\end{array}$ & & & & \\
$\begin{array}{r}\text { January-June year } \\
1\end{array}$ & $1,279(20.5 \%)$ & $1,930(30.9 \%)$ & $1,974(31.6 \%)$ & $1,070(17.1 \%)$ \\
$\quad$ July-December & $1,061(18.2 \%)$ & $1,836(31.4 \%)$ & $1,917(32.8 \%)$ & $1,029(17.6 \%)$ \\
$\begin{array}{r}\text { year 1 } \\
\text { January-June year }\end{array}$ & $1,271(19.7 \%)$ & $1,824(28.2 \%)$ & $2,266(35.0 \%)$ & $1,105(17.1 \%)$ \\
2 & $1,351(19.9 \%)$ & $1,801(26.5 \%)$ & $2,446(36.0 \%)$ & $1,198(17.6 \%)$ \\
\hline \begin{tabular}{l} 
July-December \\
\hline
\end{tabular}
\end{tabular}




\begin{tabular}{|c|c|c|c|c|}
\hline \multicolumn{5}{|l|}{ year 2} \\
\hline $\begin{array}{l}\text { Low density area } \\
\text { for ethnic }\end{array}$ & & & & \\
\hline No & $1,821(17.3 \%)$ & $2,692(25.6 \%)$ & $4,106(39.1 \%)$ & $1,894(18.0 \%)$ \\
\hline Yes & $3,141(21.2 \%)$ & 4,699 (31.7\%) & $4,497(30.3 \%)$ & $2,508(16.9 \%)$ \\
\hline \multicolumn{5}{|l|}{$\begin{array}{l}\text { Office Region } \\
\text { (GOR) }\end{array}$} \\
\hline North East & 192 (16.7\%) & 348 (30.3\%) & 359 (31.2\%) & 250 (21.8\%) \\
\hline North West & 514 (18.4\%) & 891 (31.8\%) & 890 (31.8\%) & $505(18.0 \%)$ \\
\hline $\begin{array}{r}\text { Yorkshire and the } \\
\text { Humber }\end{array}$ & $458(21.7 \%)$ & 661 (31.4\%) & 626 (29.7\%) & 361 (17.1\%) \\
\hline East Midlands & 342 (19.0\%) & 610 (33.9\%) & 494 (27.4\%) & 356 (19.8\%) \\
\hline West Midlands & $502(21.6 \%)$ & $693(29.8 \%)$ & $751(32.3 \%)$ & 378 (16.3\%) \\
\hline East of England & $481(19.3 \%)$ & $773(31.0 \%)$ & 845 (33.9\%) & 396 (15.9\%) \\
\hline London & 557 (15.1\%) & 722 (19.6\%) & $1,755(47.7 \%)$ & 647 (17.6\%) \\
\hline South East & 792 (21.9\%) & 1,047 (29.0\%) & $1,151(31.9 \%)$ & $619(17.2 \%)$ \\
\hline South West & 407 (20.5\%) & 655 (33.1\%) & $618(31.2 \%)$ & 301 (15.2\%) \\
\hline Wales & 243 (21.4\%) & 351 (31.0\%) & 331 (29.2\%) & 209 (18.4\%) \\
\hline Scotland & $474(20.8 \%)$ & $640(28.1 \%)$ & 783 (34.4\%) & $380(16.7 \%)$ \\
\hline \multicolumn{5}{|l|}{ Urban/rural } \\
\hline Urban area & $3,886(18.7 \%)$ & $5,861(28.2 \%)$ & 7,369 (35.4\%) & $3,676(17.7 \%)$ \\
\hline Rural area & $1,076(23.6 \%)$ & $1,530(33.5 \%)$ & $1,234(27.0 \%)$ & 726 (15.9\%) \\
\hline \multicolumn{5}{|l|}{$\begin{array}{l}\text { Interviewer } \\
\text { observations } \\
\text { Barrier } 2 \text { (locked } \\
\text { gates) }\end{array}$} \\
\hline Not mentioned & 4,882 (19.6\%) & 7,311 (29.3\%) & 8,395 (33.7\%) & $4,324(17.4 \%)$ \\
\hline Mentioned & $80(17.9 \%)$ & $80(17.9 \%)$ & 208 (46.6\%) & $78(17.5 \%)$ \\
\hline \multicolumn{5}{|l|}{ Accommodation } \\
\hline $\begin{array}{r}\text { Detached } \\
\text { house/bungalow }\end{array}$ & $1,273(24.8 \%)$ & 1,743 (33.9\%) & 1,325 (25.8\%) & 799 (15.5\%) \\
\hline $\begin{array}{l}\text { Semi-detached } \\
\text { house/bungalow }\end{array}$ & 1,615 (22.0\%) & $2,306(31.4 \%)$ & $2,188(29.8 \%)$ & 1,242 (16.9\%) \\
\hline $\begin{array}{r}\text { Terraced } \\
\text { house/end } \\
\text { terraced } \\
\text { house/bungalow }\end{array}$ & 1,330 (17.6\%) & $2,153(28.5 \%)$ & $2,613(34.5 \%)$ & 1,467 (19.4\%) \\
\hline $\begin{array}{r}\text { Flats/maisonettes } \\
\text { purpose built or } \\
\text { converted }\end{array}$ & 698 (13.6\%) & $1,143(22.2 \%)$ & $2,432(47.3 \%)$ & 869 (16.9\%) \\
\hline $\begin{array}{r}\text { Bedsitters, } \\
\text { dwellings with } \\
\text { business and } \\
\text { sheltered } \\
\text { accommodation }\end{array}$ & 46 (28.4\%) & 46 (28.4\%) & $45(27.8 \%)$ & 25 (15.4\%) \\
\hline \multicolumn{5}{|l|}{ Floor } \\
\hline 0 floors & 32 (38.6\%) & 44 (39.3\%) & 17 (15.2\%) & 19 (17.0\%) \\
\hline 1 floor & 771 (22.2\%) & $1,053(30.3 \%)$ & $1,086(31.3 \%)$ & 565 (16.3\%) \\
\hline 2 floors & $3,666(20.2 \%)$ & $5,520(30.4 \%)$ & $5,749(31.7 \%)$ & $3,195(17.6 \%)$ \\
\hline
\end{tabular}




\begin{tabular}{|c|c|c|c|c|}
\hline 3 floors & 288 (13.4\%) & $526(24.6 \%)$ & 917 (42.8\%) & 411 (19.2\%) \\
\hline 4 floors and above & 205 (13.7\%) & 248 (16.5\%) & 834 (55.6\%) & 212 (14.1\%) \\
\hline \multicolumn{5}{|l|}{ Car/van } \\
\hline $\begin{array}{r}\text { Definitely has a } \\
\text { car/van }\end{array}$ & $1,855(20.1 \%)$ & $3,221(35.0 \%)$ & 2,482 (27.0\%) & $1,650(17.9 \%)$ \\
\hline Likely & $1,092(20.8 \%)$ & $1,544(29.4 \%)$ & 1,698 (32.4\%) & 912 (17.4\%) \\
\hline Unlikely & 269 (25.8\%) & 258 (24.7\%) & 378 (36.2\%) & 138 (13.2\%) \\
\hline Definitely does & 103 (15.4\%) & 314 (46.9\%) & $103(15.4 \%)$ & 150 (22.4\%) \\
\hline not have a car/van & & & & \\
\hline $\begin{array}{r}\text { Cannot tell from } \\
\text { observation }\end{array}$ & $1,643(17.9 \%)$ & $2,054(22.3 \%)$ & 3,942 (42.9\%) & 1,552 (16.9\%) \\
\hline \multicolumn{5}{|l|}{ Child } \\
\hline $\begin{array}{r}\text { Definitely has a } \\
\text { child/children } \\
\text { aged under } 10\end{array}$ & 247 (14.8\%) & $606(36.4 \%)$ & $446(26.8 \%)$ & 365 (21.9\%) \\
\hline Likely & 360 (16.4\%) & 768 (34.9\%) & 648 (29.4\%) & 425 (19.3\%) \\
\hline Unlikely & $1,172(22.7 \%)$ & $1,458(28.3 \%)$ & 1,694 (32.9\%) & 828 (16.1\%) \\
\hline $\begin{array}{r}\text { Definitely does } \\
\text { not have a } \\
\text { child/children } \\
\text { aged under } 10\end{array}$ & $823(21.2 \%)$ & $1,310(33.7 \%)$ & $1,041(26.8 \%)$ & 714 (18.4\%) \\
\hline $\begin{array}{r}\text { Cannot tell from } \\
\text { observation }\end{array}$ & 2,360 (19.0\%) & 3,249 (26.1\%) & 4,774 (38.3\%) & $2,070(16.6 \%)$ \\
\hline \multicolumn{5}{|l|}{ Unkempt garden } \\
\hline Yes & 359 (15.4\%) & 642 (27.5\%) & 890 (38.1\%) & 445 (19.0\%) \\
\hline No & $3,670(21.4 \%)$ & 5,337 (31.2\%) & $5,221(30.5 \%)$ & $2,900(16.9 \%)$ \\
\hline $\begin{array}{r}\text { No obvious } \\
\text { garden }\end{array}$ & $933(15.8 \%)$ & $1,412(24.0 \%)$ & $2,492(42.3 \%)$ & $1,057(17.9 \%)$ \\
\hline \multicolumn{5}{|l|}{$\begin{array}{l}\text { Relative } \\
\text { conditions of the } \\
\text { address to other } \\
\text { residential } \\
\text { properties }\end{array}$} \\
\hline Better & 351 (17.8\%) & 703 (35.7\%) & 561 (28.5\%) & 356 (18.1\%) \\
\hline About the same & 4,272 (19.9\%) & 6,245 (29.0\%) & 7,257 (33.8\%) & $3,724(17.3 \%)$ \\
\hline Worse & 314 (17.5\%) & 429 (23.9\%) & 733 (40.9\%) & 317 (17.7\%) \\
\hline $\begin{array}{l}\text { Unable to obtain } \\
\text { information }\end{array}$ & $25(26.0 \%)$ & $14(14.6 \%)$ & $52(54.2 \%)$ & $5(5.2 \%)$ \\
\hline \multicolumn{5}{|l|}{$\begin{array}{l}\text { Call Record } \\
\text { Variables } \\
\text { Time of day call } \\
1\end{array}$} \\
\hline $\begin{array}{r}\text { Morning (0- } \\
12.00)\end{array}$ & 921 (19.7\%) & 1,359 (29.0\%) & 1,564 (33.4\%) & 838 (17.9\%) \\
\hline $\begin{array}{r}\text { Afternoon (12.00- } \\
17.00)\end{array}$ & 3,353 (19.6\%) & $5,132(30.0 \%)$ & $5,684(33.2 \%)$ & $2,963(17.3 \%)$ \\
\hline $\begin{array}{r}\text { Evening (17.00- } \\
24.00)\end{array}$ & 688 (19.4\%) & $900(25.4 \%)$ & 1,355 (38.2\%) & 601 (17.0\%) \\
\hline \multicolumn{5}{|l|}{$\begin{array}{l}\text { Time of day call } \\
2\end{array}$} \\
\hline Morning (0- & 961 (20.5\%) & $1,416(30.2 \%)$ & 1,563 (33.3\%) & $751(16.0 \%)$ \\
\hline
\end{tabular}




\begin{tabular}{|c|c|c|c|c|}
\hline 12.00) & & & & \\
\hline $\begin{array}{r}\text { Afternoon (12.00- } \\
17.00)\end{array}$ & $2,682(19.6 \%)$ & 3,971 (29.1\%) & $4,516(33.0 \%)$ & $2,500(18.3 \%)$ \\
\hline $\begin{array}{r}\text { Evening (17.00- } \\
24.00)\end{array}$ & 1,319 (18.8\%) & $2,004(28.6 \%)$ & $2,524(36.1 \%)$ & $1,151(16.4 \%)$ \\
\hline \multicolumn{5}{|l|}{$\begin{array}{l}\text { Time between } \\
\text { call } 1 \text { and call } 2 \\
\text { Time of day call } \\
3\end{array}$} \\
\hline Morning(0-12.00) & 979 (21.0\%) & 1,367 (29.3\%) & 1,536 (33.0\%) & 777 (16.7\%) \\
\hline $\begin{array}{r}\text { Afternoon (12.00- } \\
17.00)\end{array}$ & $2,455(20.8 \%)$ & 3,346 (28.4\%) & $3,870(32.9 \%)$ & $2,104(17.9 \%)$ \\
\hline $\begin{array}{r}\text { Evening (17.00- } \\
24.00)\end{array}$ & $1,528(17.1 \%)$ & $2,678(30.0 \%)$ & 3,197 (35.8\%) & $1,521(17.0 \%)$ \\
\hline \multicolumn{5}{|l|}{$\begin{array}{l}\text { Time between } \\
\text { call } 2 \text { and call } 3 \\
\text { Call } 1 \text { outcome }\end{array}$} \\
\hline No contact & 2,735 (15.6\%) & $5,141(29.4 \%)$ & $6,400(36.5 \%)$ & 3,240 (18.5\%) \\
\hline Contact made & 1,527 (28.6\%) & 1,430 (26.8\%) & 1,609 (30.1\%) & 776 (14.5\%) \\
\hline $\begin{array}{r}\text { Appointment } \\
\text { made }\end{array}$ & 310 (19.8\%) & 599 (38.3\%) & 370 (23.7\%) & 285 (18.2\%) \\
\hline Any other status & 355 (43.7\%) & 166 (20.4\%) & 209 (25.7\%) & $82(10.1 \%)$ \\
\hline Interview done & 35 (28.2\%) & 55 (44.4\%) & 15 (12.1\%) & $19(15.3 \%)$ \\
\hline \multicolumn{5}{|l|}{ Call 2 outcome } \\
\hline No contact & $2,603(15.6 \%)$ & 4,622 (27.6\%) & 6,297 (37.6\%) & $3,216(19.2 \%)$ \\
\hline Contact made & 1,283 (25.3\%) & 1,412 (27.9\%) & 1,626 (32.1\%) & 746 (14.7\%) \\
\hline $\begin{array}{r}\text { Appointment } \\
\text { made }\end{array}$ & 332 (17.1\%) & $883(45.6 \%)$ & 418 (21.6\%) & 304 (15.7\%) \\
\hline Any other status & 611 (54.3\%) & 197 (17.5\%) & 232 (20.6\%) & 85 (7.6\%) \\
\hline Interview done & 133 (27.1\%) & 277 (56.4\%) & $30(6.1 \%)$ & $51(10.4 \%)$ \\
\hline \multicolumn{5}{|l|}{ Call 3 outcome } \\
\hline No contact & 2,706 (17.7\%) & $3,000(19.7 \%)$ & 6,328 (41.5\%) & $3,219(21.1 \%)$ \\
\hline Contact made & $1,170(26.4 \%)$ & $1,026(23.2 \%)$ & 1,547 (35.0\%) & 683 (15.4\%) \\
\hline $\begin{array}{r}\text { Appointment } \\
\text { made }\end{array}$ & $176(5.1 \%)$ & 2,617 (75.1\%) & $352(10.1 \%)$ & $340(9.8 \%)$ \\
\hline Any other status & 707 (55.3\%) & 153 (12.0\%) & 324 (25.4\%) & 94 (7.4\%) \\
\hline Interview done & $203(22.2 \%)$ & 595 (65.0\%) & $52(5.7 \%)$ & $66(7.2 \%)$ \\
\hline
\end{tabular}

Figure A1: [Figure 1 from text in greyscale.] 
Predicted probabilities for the final combined model (final outcome and length) for selected explanatory variables (one variable from each group of explanatory variables in Model 6)

a.)

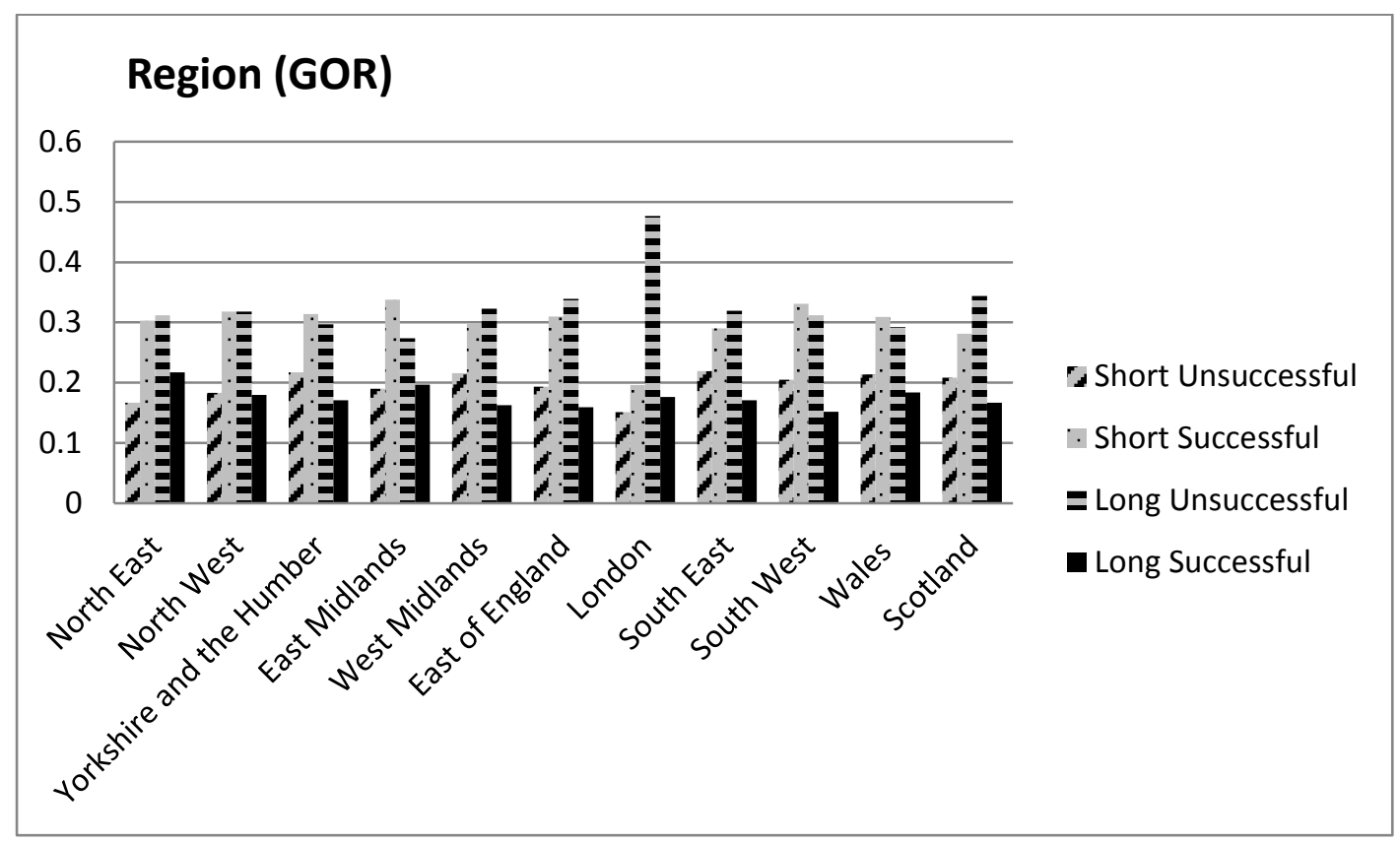

b.)

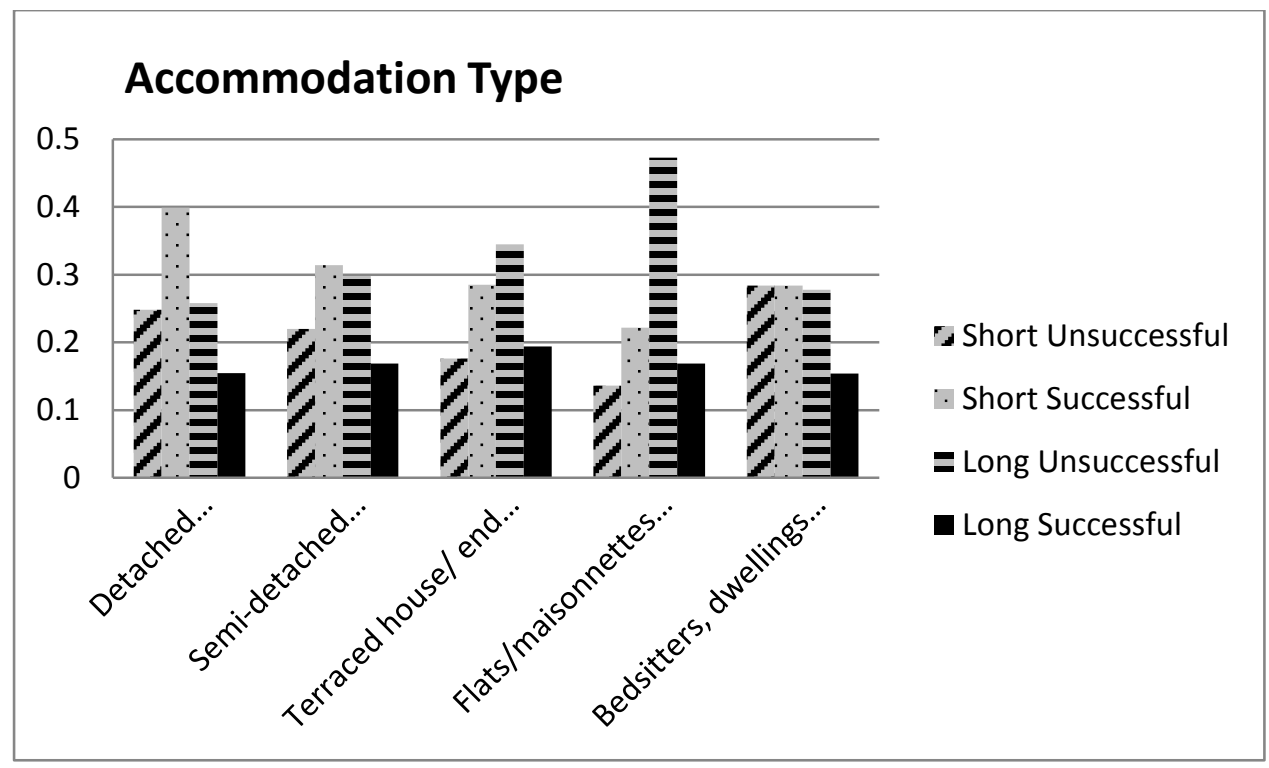


c.)

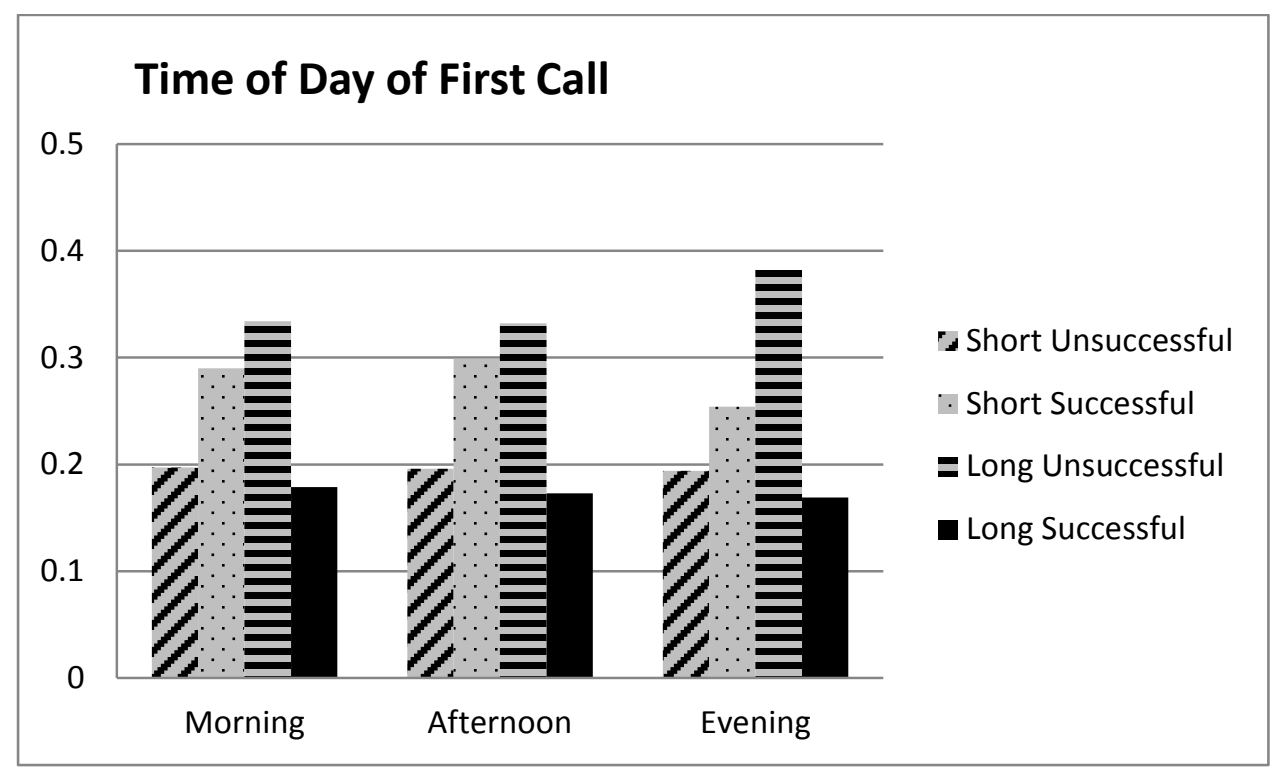

d.)

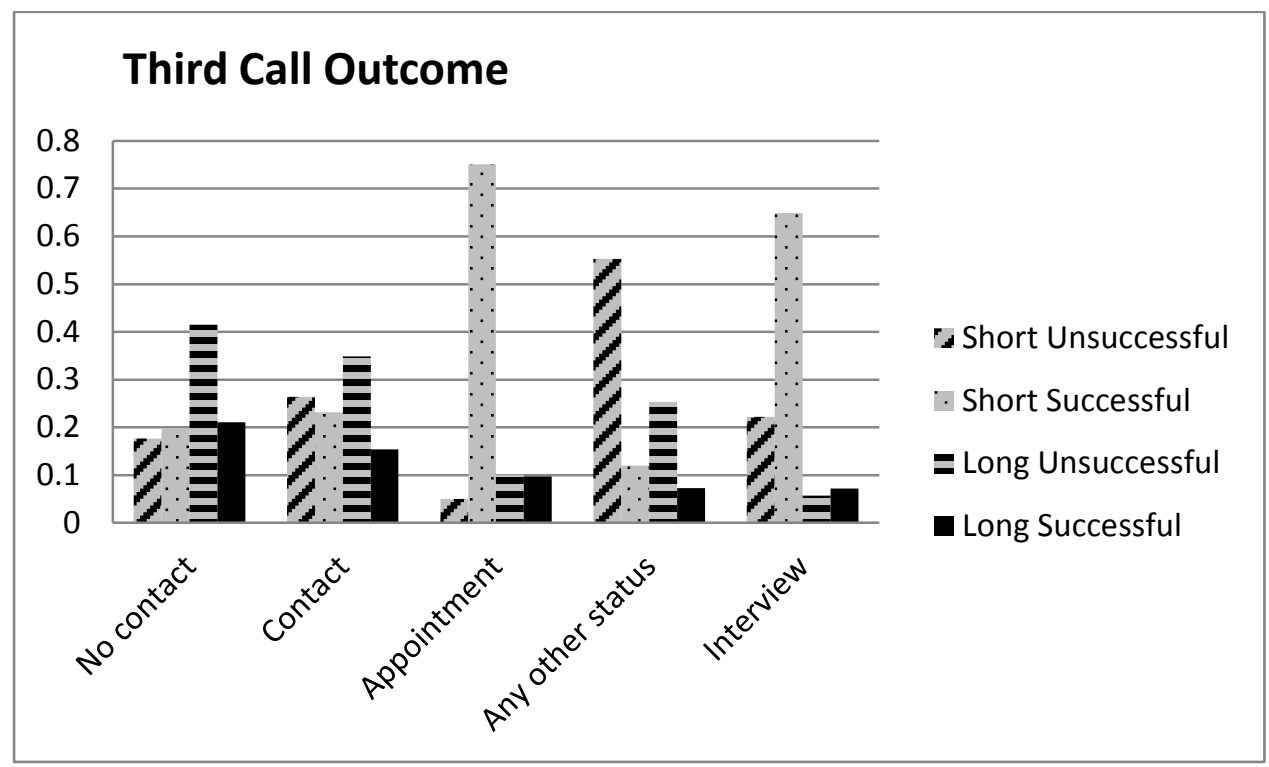

